From Subduction to Collision in the Northern Tibetan Plateau: Evidence from the Early Silurian Clastic Rocks, Northwestern China

Author(s): Jianghai Yang, Yuansheng Du, Peter A. Cawood, Yajun Xu

Reviewed work(s):

Source: The Journal of Geology, Vol. 120, No. 1 (January 2012), pp. 49-67

Published by: The University of Chicago Press

Stable URL: http://www.jstor.org/stable/10.1086/662717

Accessed: 09/01/2012 03:53

Your use of the JSTOR archive indicates your acceptance of the Terms \& Conditions of Use, available at http://www.jstor.org/page/info/about/policies/terms.jsp

JSTOR is a not-for-profit service that helps scholars, researchers, and students discover, use, and build upon a wide range of content in a trusted digital archive. We use information technology and tools to increase productivity and facilitate new forms of scholarship. For more information about JSTOR, please contact support@jstor.org. 


\title{
From Subduction to Collision in the Northern Tibetan Plateau: Evidence from the Early Silurian Clastic Rocks, Northwestern China
}

\author{
Jianghai Yang, ${ }^{1}$ Yuansheng Du, ${ }^{1,2, \star}$ Peter A. Cawood, ${ }^{3}$ and Yajun $X u^{1}$ \\ 1. State Key Laboratory of Biogeology and Environmental Geology, China University of Geosciences, Wuhan \\ 430074, China; 2. State Key Laboratory of Geological Processes and Mineral Resources, China University of \\ Geosciences, Wuhan 430074, China; 3. Department of Earth Sciences, University of St. Andrews, North Street, \\ St. Andrews KY16 9AL, United Kingdom; and School of Earth and Environment, University of Western Australia, \\ 35 Stirling Highway, Crawley, Western Australia 6009, Australia
}

\begin{abstract}
A B S T R A C T
The Qilian Orogen records early Paleozoic collisional suturing of the Qaidam Block and the Central Qilian Block to the North China Craton. The composition and U-Pb age of detrital zircons and the composition of Cr-spinels from the Early Silurian Lujiaogou and Angzanggou formations in the northern part of orogen indicate derivation from evolving oceanic and continental source terranes. Heavy-mineral chemistry indicates the incorporation of suprasubduction zone-type ophiolitic detritus in addition to continent-derived material. Integrating these chemical and age data with regional data on the duration of subduction-related magmatic activity, syn- and postcollisional granitic rocks, and high-pressure metamorphic rocks constrains the transformation from oceanic subduction to continental collision to 450-440 Ma. The collision resulted in a flood of detritus into the northern part of the orogen from the Central Qilian Block, which masked input from the intervening magmatic arc, implying rapid exposure of the block.
\end{abstract}

Online enhancements: appendix tables.

\section{Introduction}

The North China Craton experienced a series of orogenic events around its margins during the early Paleozoic (Chen et al. 1997; de Jong et al. 2006; Kusky et al. 2007; Zhang et al. 2008b). The Qilian Orogen lies along the western border of the craton and represents the northernmost part of the Tibetan Plateau (fig. 1 $a$; Gehrels et al. 2003a; Song et al. 2006; Xu et al. 2006). The orogen records earlymid-Paleozoic ocean closure and continental collision (Zuo and Liu 1987; Xu et al. 1994; Feng and He 1996; Bian et al. 2001; Du et al. 2004; Song et al. 2009). New detrital-zircon U-Pb ages and the geochemistry of heavy minerals from the Early Silurian sequences from the North Qilian orogen, combined with regional data on pre-, syn-, and post2011 .

Manuscript received January 8, 2011; accepted September 13,

* Author for correspondence; e-mail: duyuansheng126@ 126.com. collision events within the orogen, enable the timing and sequence of collisional events to be accurately constrained.

\section{Regional Geology}

The north-northwest-trending Qilian Orogen $\left(35^{\circ}-\right.$ $40^{\circ} \mathrm{N}, 94^{\circ}-107^{\circ} \mathrm{E}$; fig. 1 a) records the early-middle Paleozoic collision between the Qaidam Block to the south and the North China Craton to the north. The orogen is fault bounded and is separated from the Tarim Block to the west by the Altyn Tagh Fault and from the North China Craton to the north and east by the Longshoushan and Tongxin-Guyuan faults, respectively (Feng and He 1996). It is separated from the Qaidam Block to the south and the Qinling Orogen to the south and southeast by a series of thrust faults (fig. $1 b$ ). The orogen is subdivided from north to south into three north-northwest-trending, fault-bounded units termed the

[The Journal of Geology, 2012, volume 120, p. 49-67] @ 2012 by The University of Chicago. All rights reserved. 0022-1376/2012/12001-0004\$15.00. DOI: 10.1086/662717 


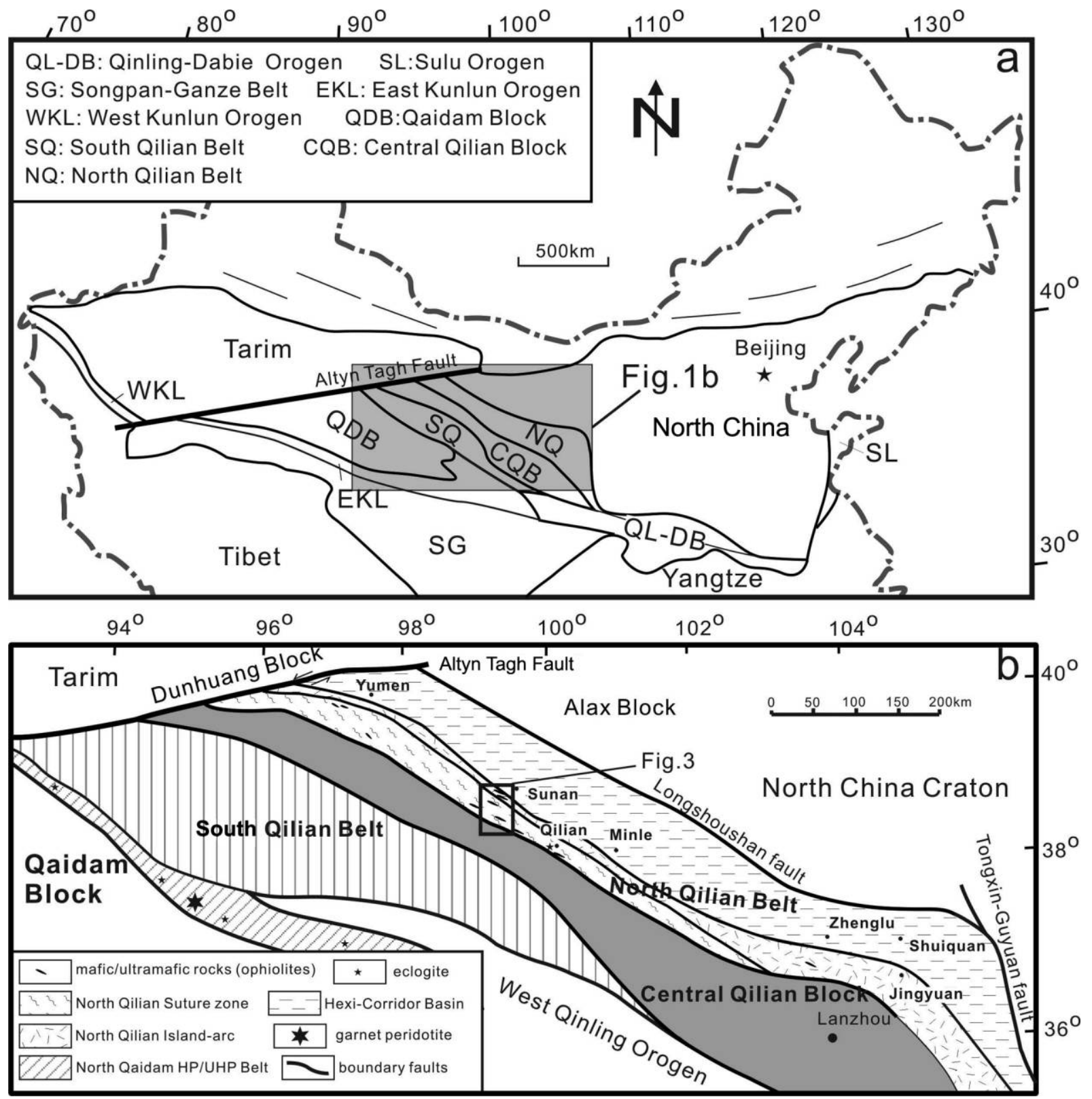

Figure 1. $a$, Major tectonic units of China. $b$, Subunits of the Qilian Orogen and the adjacent regions. Revised from Feng and He (1996) and Xu et al. (2006). Study area marked by the box.

North Qilian Belt, the Central Qilian Block, and the South Qilian Belt.

The North Qilian Belt (fig. 1b) consists of a broad suture zone, termed the North Qilian suture, the North Qilian island arc, and the Hexi-Corridor Basin. The suture zone marks the boundary with the Central Qilian Block. The suture zone along the south of the Cambro-Ordovician suprasubduction zone (SSZ) arc sequences contains accretionarywedge, high-pressure metamorphic rocks, mafic/ultramafic rocks, and probably lensoidal Precambrian fragments (Xiao et al. 1978; Wu et al. 1993; Xia et al. 1995; Feng and He 1996; Zhou et al. 1996; Song et al. 2004; Du et al. 2007). From the Cambrian to the Devonian, the Hexi-Corridor Basin evolved from a volcanosedimentary basin to one filled with siliciclastic rocks and intercalated carbonates that records the change from oceanic subduction and closure to the continental collision of the Central Qilian Block and the North China Craton (BGMRGP 1989; Feng and He 1996; Qian et al. 2001; Du et al. 2003). Metamorphic and magmatic 
assemblages within the North Qilian Belt include blueschist-eclogite metamorphic rocks, ophiolites, island-arc volcanic and I-type granitic rocks, and syn- and postcollisional granitic rocks (fig. 2; Liou et al. 1989; BGMRQP 1991; Wu et al. 1993, 2005; Xia et al. 1995, 2003; Zhang et al. 1995, 1997; Mao et al. 1999, 2000; Chen et al. 2002; Shi et al. 2004b; Song et al. 2004; Wang et al. 2005a; Chen 2007; Liu et al. 2007; Tseng et al. 2007; Xia and Song 2010; Yu et al. 2010).

The Central Qilian Block is composed mainly of Proterozoic granitic gneiss and siliciclastic and carbonate metasedimentary rocks (Wan et al. 2000, 2001; Smith 2006). These basement rocks have a Yangtze (Gondwana) affinity based on geochronology, geochemistry, and paleontology (Zhang et al. 1998a, 2006; Guo et al. 2000; Wan et al. 2000, 2006; Gehrels et al. 2003a; Tung et al. 2007a; Xu et al. 2006, 2007; Yong et al. 2008a). The Neoproterozoic basement assemblage within the belt underwent early Paleozoic orogeny (BGMRQP 1991; Fan and Lei 2007; He et al. 2007; Chen et al. 2008; Yong et al. 2008b; Tseng et al. 2009). Paleozoic granitic intrusions within the belt can be grouped into subduction-related I-type, syncollisional S-type, and postcollisional I-type on the basis of geochemistry, and they range in age from 488 to $382 \mathrm{Ma}$ (fig. 2; BGMRQP 1991; Su et al. 2004; Chen et al. 2008; Yong et al. 2008b).
The South Qilian Belt records the collision between the Qaidam Block and the Central Qilian Block (Xu et al. 2006). Lithologic units include Cambrian-Ordovician lava flows, pyroclastic rocks and bathyal deposits, Silurian flysch, and the early Paleozoic North Qaidam ultrahigh-pressure (UHP) metamorphic belt, which fringes its southern margin (Yang et al. 2000; Xu et al. 2006). Within or north of the UHP belt are island-arc magmatic rocks and syn- and postcollisional granitic rocks dated by zircon U-Pb geochronology from 514 to 372 Ma (fig. 2; Shi et al. 2004a; Wu et al. 2006, 2007, 2009).

\section{Sampled Silurian Strata}

Silurian strata in the North Qilian Belt occur within the Hexi-Corridor Basin and consist of a thick turbidite clastic succession with minor volcanic rocks, tuffs, tuffaceous sandstones, and intercalated limestones and cherts. They are unconformably overlain by lower-middle Devonian molasse deposits (BGMRGP 1989). The succession in the basin is divided into the Sunan Subprovince in the west and the Jingyuan Subprovince in the east (see Shuiquan Section; Yang et al. 2009) on the basis of contrasting litho- and biostratigraphic relations (Regional Geological Surveying Team 1986). Our sampled section is in the Sunan Subprovince,

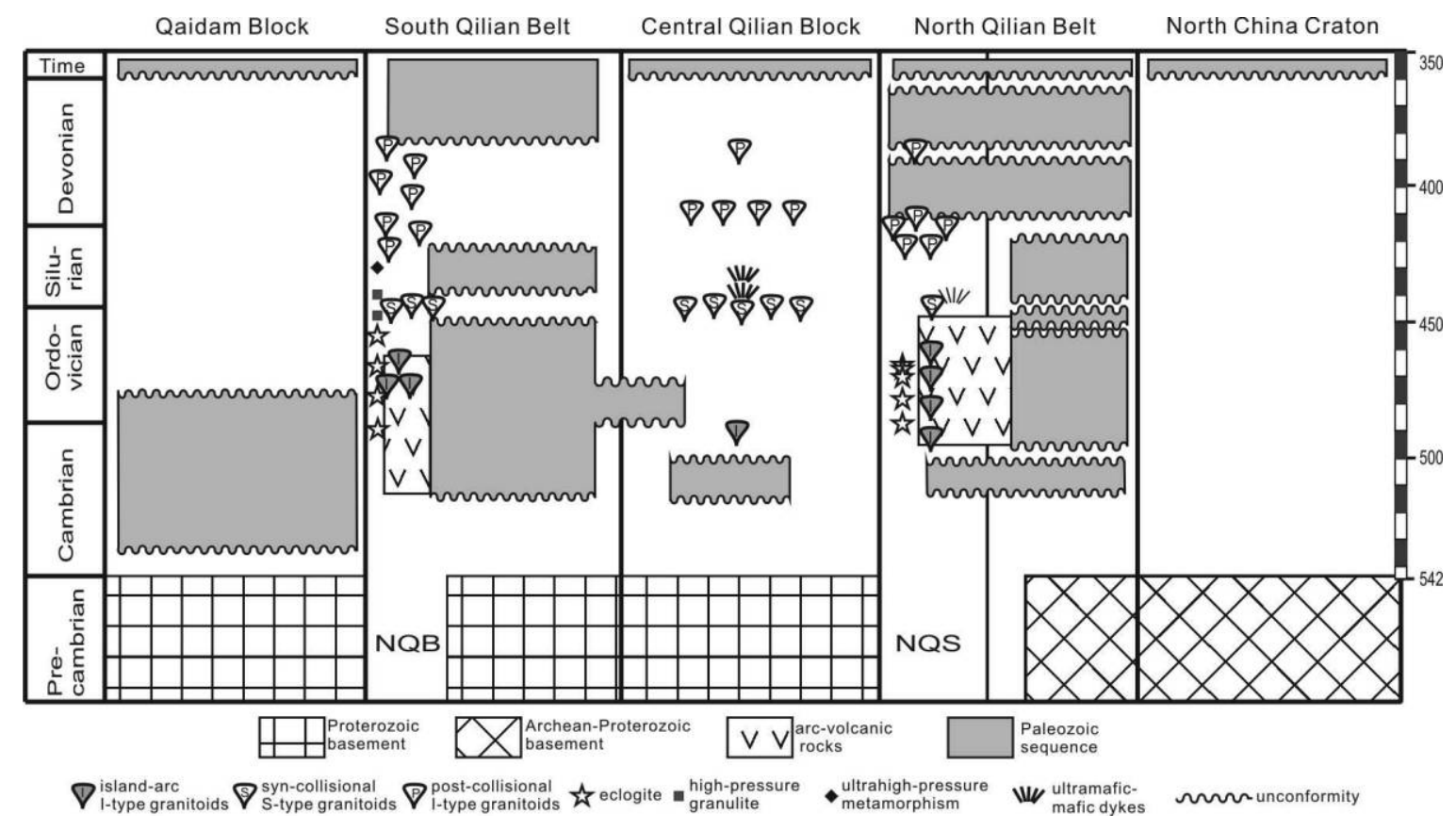

Figure 2. Time-space diagram outlining age ranges of magmatism, metamorphism, and sedimentation related to the Paleozoic orogeny in the Qilian Orogen. NQB = North Qaidam ultrahigh-pressure metamorphic belt; NQS = North Qilian Suture Zone. 
south of Sunan County (fig. 3). From north to south, the major units, often with faulted contacts, are Silurian clastic rocks, an Ordovician back-arc volcanosedimentary sequence, Ordovician island-arc volcanic rocks, a mid-ocean and fore-arc complex, and the Central Qilian Precambrian basement (fig. 3; Feng and He 1996; Xia et al. 2003).

The sampled Silurian strata unconformably overlie Ordovician grayish-green phyllitic slates (fig. $4 a$ ). They include, from base to top, the lower Silurian Lujiaogou and Angzanggou formations, the middle Silurian Quannaogoushan Formation, and the upper Silurian Hanxia Formation. Contacts between units are conformable. Our samples are from the lower Silurian, which consists of conglomerates and intercalated sandstones in the lower Lujiaogou Formation and siltstone and shale in the upper Angzanggou Formation (fig. 3). The pebbles in the conglomerates are mainly subangular to angular vol- canic rocks, rounded to subrounded black-green cherts, and gray quartz with some greenschist (fig. $4 b)$. The interbedded coarse to medium sandstones are mainly composed of volcanic lithic fragments, chert fragments, and quartz grains, with rare feldspars and sedimentary lithic fragments.

\section{Analytical Methods}

Analyses were undertaken at the State Key Laboratory of Geological Processes and Mineral Resources, China University of Geosciences (Wuhan). Spinel grain compositions were determined from polished thin sections on a JEOL JXA-8100 electron microprobe. The analyses were performed under the following conditions: accelerating voltage of 15 $\mathrm{kV}$, a specimen current of $20 \mathrm{nA}$, and a beam size of $5 \mu \mathrm{m}$ using the ZAF correction model. The analytical uncertainties are generally less than $2 \%$.

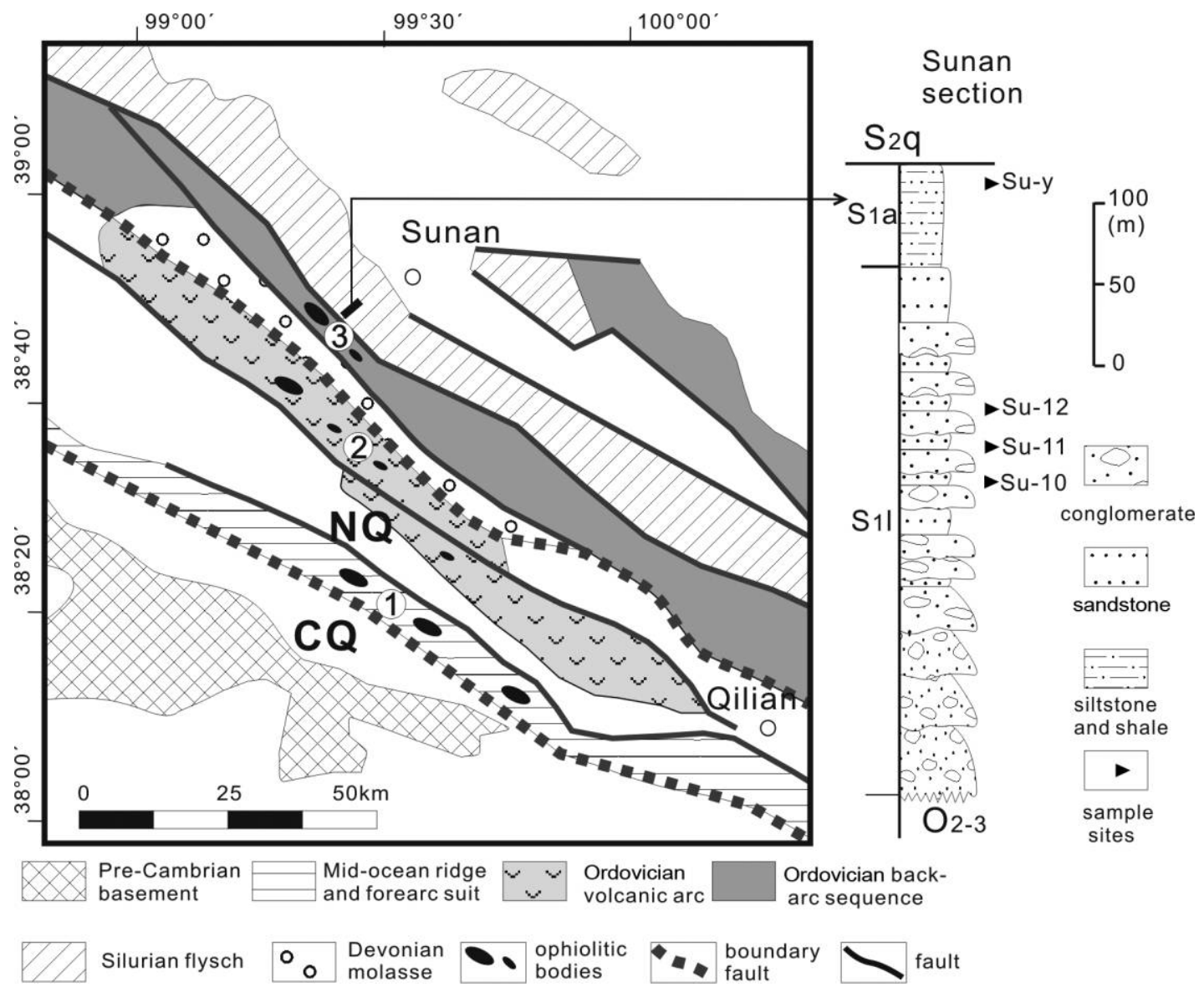

Figure 3. Left, Geological map showing major lithologic assemblages in the Sunan area (revised from Feng and He 1996). NQ = North Qilian Belt; CQ = Central Qilian Block. Locations of three ophiolites are marked: Yushigou (1), Dachadaban (2), and Jiugequan (3). Right, measured section showing relative position of samples. $\mathrm{O}_{2-3}=$ middleupper Ordovician; $\mathrm{S}_{1} 1=$ Early Silurian Lujiaogou Formation; $\mathrm{S}_{1} \mathrm{a}=$ Early Silurian Angzanggou Formation; $\mathrm{S}_{2} \mathrm{q}=$ Middle Silurian Quannaogoushan Formation. 

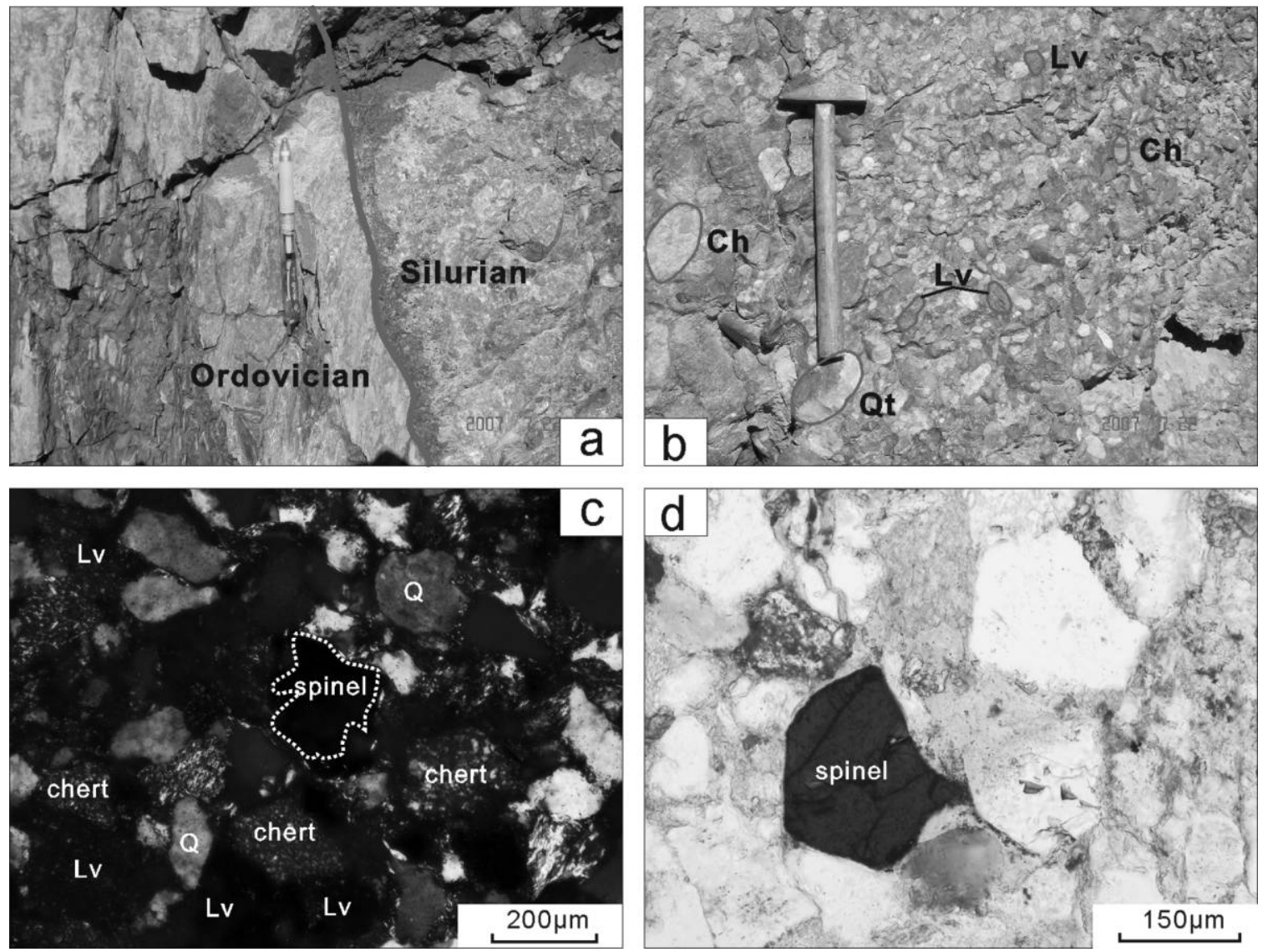

Figure 4. $a$, Unconformable contact between the metamorphosed middle-upper Ordovician and the unmetamorphosed Early Silurian, about $10 \mathrm{~km}$ south of Sunan County. Pen is $10 \mathrm{~cm}$ long, for scale, and photo is looking toward the east. b, Lujiaogou Formation conglomerates, Sunan Section. Hammer is $35 \mathrm{~cm}$, for scale, and photo is looking toward the east. The major pebbles are subangular to angular volcanic rocks (Lv), rounded to subrounded black-green cherts $(\mathrm{Ch})$, and gray quartz $(\mathrm{Qt})$. c , Photomicrograph (cross-polarized light) for sample Su-12, showing the detrital components: volcanic fragments (Lv), quartz grains (Q), chert fragments, and one detrital Cr-spinel grain. $d$, Microphotograph under plane-polarized light for a detrital Cr-spinel surrounded by matrix and quartzes. A color version of this figure is available in the online edition or from the Journal of Geology office.

The detection limits of the major elements are lower than $0.0060 \%$. All $\mathrm{Fe}$ is expressed as $\mathrm{FeO}$, and the ferric iron content of each analysis was determined by assuming stoichiometry and an ideal $\mathrm{XYO}_{4}$ formula with Ti in ulvospinel component, following the methods of Barnes and Roeder (2001).

Zircons for analysis were separated from rock samples by standard techniques, mounted in epoxy, and polished. The surface of the grain mounts was acid-washed in dilute $\mathrm{HNO}_{3}$ to suppress lead contamination. Cathodoluminescence images were also obtained on the JEOL JXA-8100 electron microprobe.

Zircon U-Pb dating was undertaken on an Agilent 7500a laser ablation (LA-)ICPMS with a Geolas 2005 laser. The detailed analytical procedure fol- lows Yuan et al. (2004). The repetition rate was 5 $\mathrm{Hz}$, and the spots were $25 \mu \mathrm{m}$ in diameter. Zircon 91500 was used as an external standard to correct for isotopic fractionation during analysis. Off-line selection and integration of background and analytic signals and time-drift correction and quantitative calibration for $\mathrm{U}-\mathrm{Pb}$ dating were performed with ICPMSDataCal (Liu et al. 2008). The ages were calculated with ISOPLOT 3.00 (Ludwig 2003). Uncertainties reported for individual ages are at $\pm 1 \sigma$. On probability density diagrams, only analyses with concordance of greater than $90 \%$ are shown.

Zircon trace-element analyses were also conducted by LA-ICPMS. The spots were $32 \mu \mathrm{m}$ in diameter. The NIST610 reference glass was used for calibrating the trace-element composition of 
zircons. The average analytical error ranges from ca. $\pm 10 \%$ for light rare earth elements (LREEs) to ca. $\pm 5 \%$ for the other REEs. Instrument and dataacquisition parameters for the LA-ICPMS are the same as those described by Yuan et al. (2004).

\section{Results}

Cr-Spinel Composition, Lujiaogou Formation. Crspinel analyses were undertaken on sample $\mathrm{Su}-12$, a coarse, gray lithic arenite from the middle part of the Lujiaogou Formation (fig. 3). This sample has higher overall $\mathrm{Cr}$ content (up to $276 \mathrm{ppm}$ ) and higher $\mathrm{Cr} / \mathrm{Ni}$ ratios relative to the remaining Sunan samples and those from the Shuiquan Section (Yang et al. 2012). It contains translucent dark reddishbrown and yellowish-brown detrital chrome spinel (fig. 4c, 4d). Grains range from 40 to $200 \mu \mathrm{m}$ in length and from euhedral to subangular, suggesting fragmentation during denudation and transportation. The analyzed grains have a wide compositional range (table A1, available in the online edition or from the Journal of Geology office). The $\mathrm{Cr}_{2} \mathrm{O}_{3}$ content ranges from $34.26 \%$ to $59.65 \%$ and is negatively correlated with $\mathrm{Al}_{2} \mathrm{O}_{3}$ content, which is in the range $10.39 \%-33.37 \%$ (fig. $5 a$ ). The $\mathrm{Fe}^{3+} \#$ (atomic ratio $\mathrm{Fe}^{3+} /\left(\mathrm{Cr}+\mathrm{Al}+\mathrm{Fe}^{3+}\right)$ ) varies from 0.02 to 0.06 . The usually low $\mathrm{TiO}_{2}$ content $(0.02 \%-$ $0.24 \%$, with most $<0.2 \%$ ) and high $\mathrm{Fe}^{2+} / \mathrm{Fe}^{3+}$ ratios of the grains suggest a predominantly peridotitic origin with a minor volcanic basaltic component for these detrital grains (fig. 5b; Lenza et al. 2000; Kamenetsky et al. 2001). The atomic ratio Mg\# $\left(\mathrm{Mg} /\left(\mathrm{Mg}+\mathrm{Fe}^{2+}\right)\right)$ varies from 0.33 to 0.72 , and the $\mathrm{Cr} \#(\mathrm{Cr} /(\mathrm{Cr}+\mathrm{Al}))$ varies from 0.41 to 0.79 , similar to that of alpine-type peridotites (Dick and Bullen 1984; fig. 5c). The analyzed spinel grains plot within the ophiolite field on both $(\mathrm{Ti} / \mathrm{Fe}) \times 100-\mathrm{Cr} /$ $\mathrm{Fe}$ and $\mathrm{Fe}^{3+}-\mathrm{Cr}-\mathrm{Al}$ diagrams and in the SSZ peridotite field on a $\mathrm{TiO}_{2}-\mathrm{Al}_{2} \mathrm{O}_{3}$ diagram (fig. $5 d-5 f_{\text {; }}$ Cookenboo et al. 1997; Chutakositkanon et al. 2001; Preston et al. 2002).

Zircon U-Pb Ages, Angzanggou Formation. Sample Su-y was selected from the upper part of the Angzanggou Formation for detrital-zircon dating (fig. 3 ). It is a grayish-yellow silty shale and is mainly composed of laminar sericites and secondary clay minerals, with minor fine quartz grains. The zircons from this shaly sample are rounded, colorless, and small (mostly less than $50 \mu \mathrm{m}$ in diameter), with indistinct internal cathodoluminescence structures. Only 23 grains were large enough to be dated, and they yielded 23 analyses ranging from Archean to Early Silurian (table A2, available in the online edition or from the Journal of Geology office; fig. 6a). Fourteen analyses with concordance $>90 \%$ clustered in three age ranges of 2074-1653, 1098852 , and 436-419 $\mathrm{Ma}$, with one grain yielding an age of $2525 \pm 16 \mathrm{Ma}$ (fig. 6 b).

Zircon Age and Trace-Element Compositions, Lujiaogou Formation. Samples Su-10 and $\mathrm{Su}-11$ are coarse, grayish lithic arenites from the middle part of the Lujiaogou Formation (fig. 3). They contain a large population of detrital zircons that are light pink to pink in color and generally euhedral to subeuhedral in shape and yield early Paleozoic ages (Yang et al. 2009). Grain size ranges from 70 to 200 $\mu \mathrm{m}$. Trace-element data for 49 of the zircon grains are listed in tables A3 and A4, available in the online edition or from the Journal of Geology office. Grains that showed significant depth-related fractionation during laser ablation or yielded strongly discordant $\mathrm{U}-\mathrm{Pb}$ ages were excluded from further consideration. The available grains displayed ages from 531 to $433 \mathrm{Ma}$, forming three age groups: Cambrian (531-492 Ma), Ordovician (487-444 Ma), and Early Silurian (443-433 Ma). All the zircon grains are rich in heavy REEs relative to LREEs, with a positive Ce anomaly and a negative $\mathrm{Eu}$ anomaly (fig. 7). Integrated with the high $\mathrm{Th} / \mathrm{U}$ ratios $(>0.3$, except two grains with $\mathrm{Th} / \mathrm{U}=0.19$ and $0.27)$ and an internal structure of well-developed oscillatory zoning (Yang et al. 2009), this REE pattern suggests an igneous origin for these zircons (Hoskin and Ireland 2000; Hoskin and Schaltegger 2003). The zircons have Hf contents of 4937-13,043 $\mathrm{ppm}$ and $\mathrm{Y}$ contents of $199-4124 \mathrm{ppm}$. The U/Yb ratios are 0.39-4.5 for the Silurian group, 0.21-3.2 for the Ordovician group, and 0.51-6.9 for the Cambrian group. On the U/Yb-Hf, Th/Y-Hf, U/Yb-Y, and $\mathrm{Th} / \mathrm{Yb}$-Y diagrams (fig. 8; Grimes et al. 2007), nearly all the Cambrian-Silurian grains plot within the continental-zircon field, with several Cambrian-Ordovician grains within the overlap region between the continental- and oceanic-crust fields.

\section{Discussion and Conclusions}

Detrital-Zircon Provenance. All Early Silurian and Late Ordovician clastic sedimentary rocks in the Hexi-Corridor Basin contain Precambrian detrital zircons that range in age from Archean to Neoproterozoic (fig. 9a-9d). The Neoarchean to early Paleoproterozoic detritus within the basin was likely derived from the adjoining North China Craton to the north, with analyzed samples and an inferred source region characterized by prominent age groups at 2.8-2.4 and 2.1-1.7 Ga (fig. 9a-9d, 9g; Kröner et al. 1988; Wan et al. 2003; Darby and Gehrels 2006; Tung et al. 2007b; Li et al. 2008). In the 

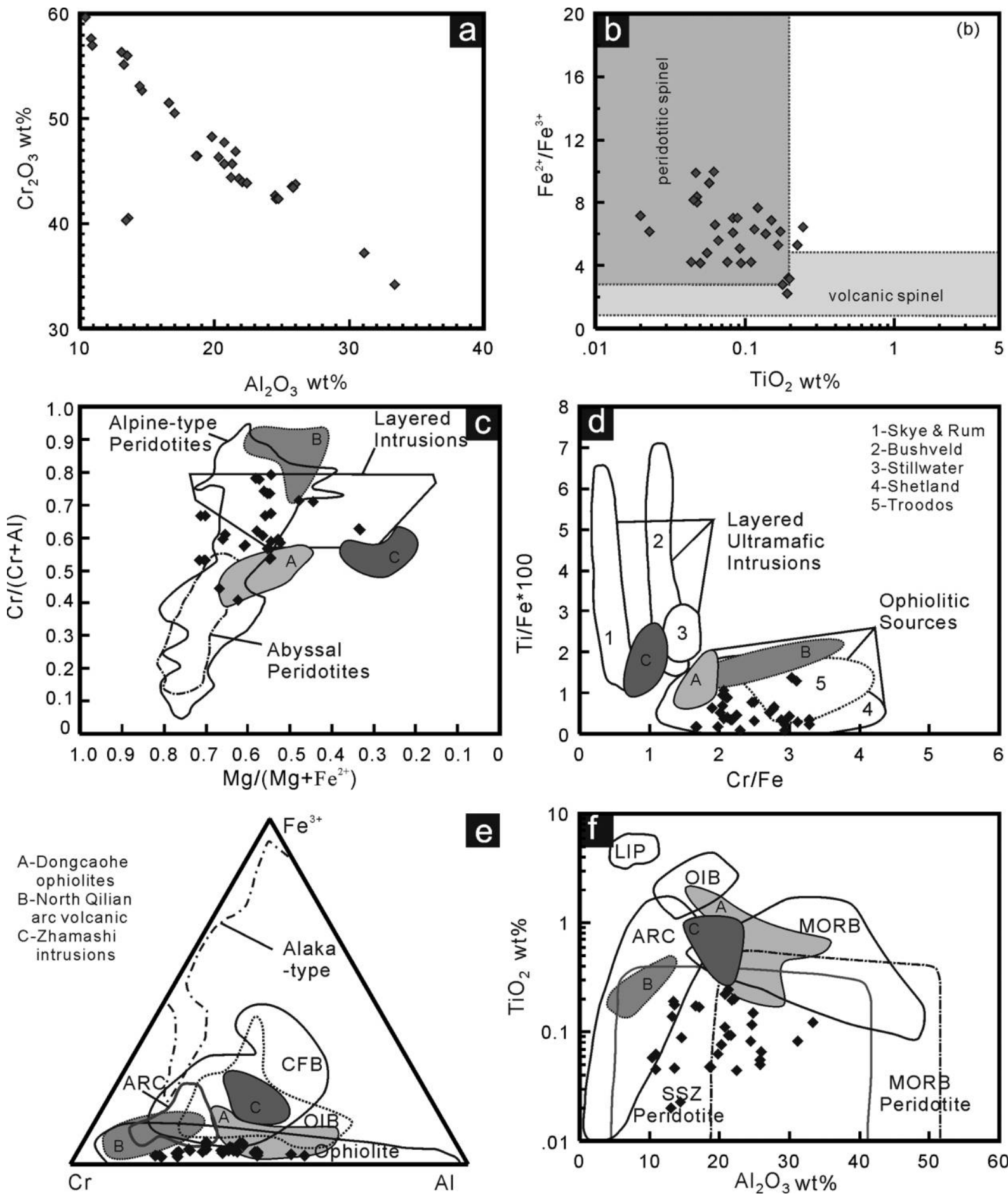

Figure 5. Geochemical discriminating diagrams for analyzed spinel grains. $a, \mathrm{C}_{2} \mathrm{O}_{3}(\mathrm{wt} \%)$ versus $\mathrm{Al}_{2} \mathrm{O}_{3}(\mathrm{wt} \%)$ plot, showing a negative correlation (except two analyses). $b, \mathrm{Fe}^{2+} / \mathrm{Fe}^{3+}$ (mole ratio) versus $\mathrm{TiO}_{2}$ (wt $\%$ ) for distinguishing peridotitic spinels from volcanic spinels (after Lenza et al. 2000). c, Cr\# (atomic ratio $\mathrm{Cr} /(\mathrm{Cr}+\mathrm{Al}))$ versus $\mathrm{Mg \#}($ atomic ratio $\left.\mathrm{Mg} /\left(\mathrm{Mg}+\mathrm{Fe}^{2+}\right)\right)$; fields after Dick and Bullen (1984). $d$, Atomic ratio (Ti/Fe) $\times 100$ versus Cr/Fe; fields after Preston et al. (2002). e, $\mathrm{Fe}^{3+}$ versus $\mathrm{Cr}$ versus Al ternary diagram; fields after Cookenboo et al. (1997). $f$, TiO $2(\mathrm{wt} \%)$ versus $\mathrm{Al}_{2} \mathrm{O}_{3}(\mathrm{wt} \%)$; fields after Kamenetsky et al. (2001). Shaded fields in $c-f: \mathrm{A}=$ Dongcaohe ophiolite data from Tseng et al. (2007); B = North Qilian arc volcanics data from Tseng et al. (2009); C = Zhamashi intrusion data from Hsu and Shau (2002). In $e$ and $f, \mathrm{ARC}=$ island-arc basalt; $\mathrm{CFB}=$ continental flood basalt; LIP $=$ large igneous province; $\mathrm{MORB}=$ mid-ocean ridge basalt; $\mathrm{OIB}=$ ocean-island basalt; $\mathrm{SSZ}=$ suprasubduction zone. 

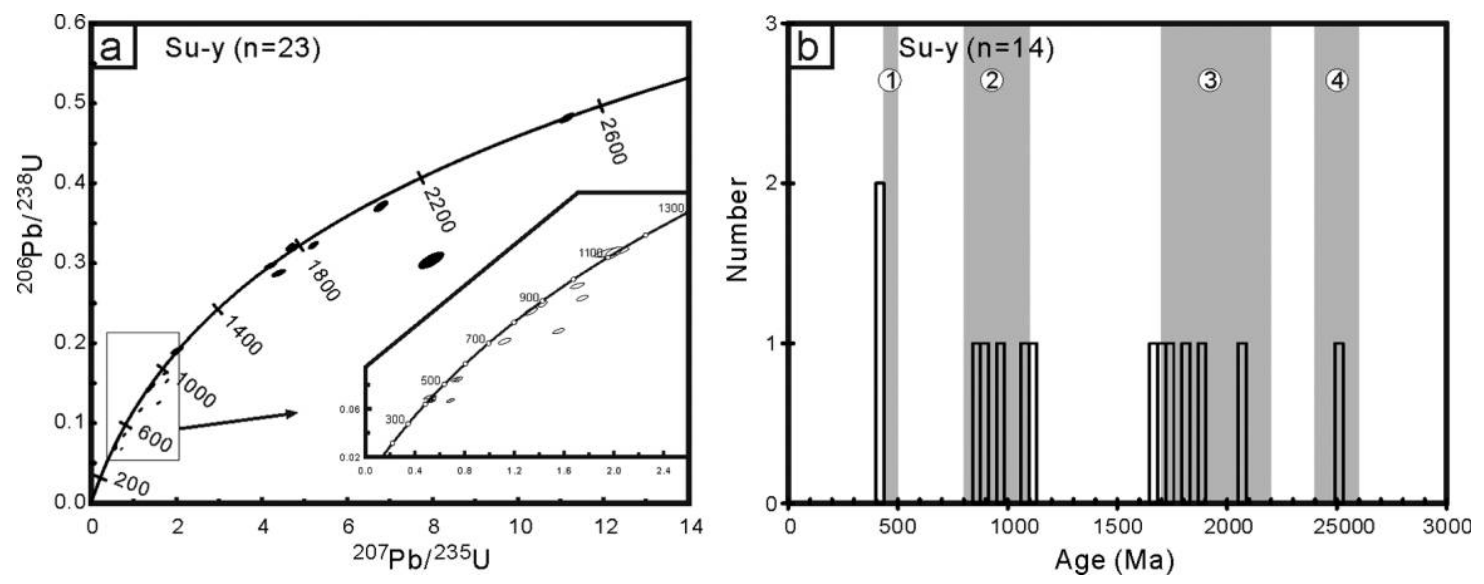

Figure 6. $a$, U-Pb concordia diagram for zircon analyses from sample Su-y. $b$, Histogram of the ages with concordance $>90 \%$. The four shaded columns represent the age ranges 0.5-0.45 Ga (1) for the North Qilian magmatic arc rocks (BGMRQP 1991; Xia et al. 1995, 2003; Zhang et al. 1997; Mao et al. 1999, 2000; Wang et al. 2005a; Chen 2007; Yu et al. 2010), 1.1-0.8 Ga (2) for the Central Qilian Block (Guo et al. 2000; Wan et al. 2000, 2001; Gehrels et al. 2003b; Tung et al. 2007a; Wang et al. 2007; Xu et al. 2007; Yong et al. 2008a; Xue et al. 2009), and 2.1-1.7 and 2.6-2.4 Ga ( 3 and 4, respectively) for the North China Craton (Kröner et al. 1988; Wan et al. 2003; Darby and Gehrels 2006; Tung et al. 2007b; Li et al. 2008).

North China Craton, these events relate to the assembly of the craton along the Trans-North China Orogen (Zhao et al. 2002; Wilde et al. 2004). The late Paleoproterozoic to Neoproterozoic detritalzircon grains in the analyzed samples were probably derived from the Central Qilian Block, where Mesoproterozoic-Neoproterozoic granitic intrusions and metamorphosed sedimentary rocks with late Paleoproterozoic to Neoproterozoic detrital zircons constitute the major part of the basement (fig. 9e, 9f; Guo et al. 2000; Wan et al. 2001; Gehrels et al. 2003a, 2003b; Tung et al. 2007a; Wang et al. 2007; Xu et al. 2007; Yong et al. 2008a; Xue et al. 2009). Cambrian-Ordovician zircon grains, in addition to Precambrian detritus, occur in the Lujiaogou Formation of the Sunan area in the Sunan Sub- province (Yang et al. 2009) and in the Late Ordovician sediments of Xiehao area in the Jingyuan Subprovince (Xu et al. 2010; fig. 9b, 9d), overlapping the ages of arc-related igneous activity and ophiolites preserved in the North Qilian suture (Xia et al. 1995, 2003; Zhang et al. 1997; Mao et al. 1999, 2000; Shi et al. 2004b; Wang et al. 2005a; Wu et al. 2005; Chen 2007; Tseng et al. 2007; Xia and Song 2010; Yu et al. 2010).

Ophiolitic Provenance. Three lines of evidence can be used to recognize ophiolitic detritus in sedimentary rocks: (1) serpentinite fragments (Arai and Okada 1991; von Eynatten 2003), (2) anomalously high concentrations of $\mathrm{Cr}$ and Ni (Hiscott 1984; Garver and Scott 1995; Garver et al. 1996; Totten et al. 2000 and references therein), and (3) the oc-

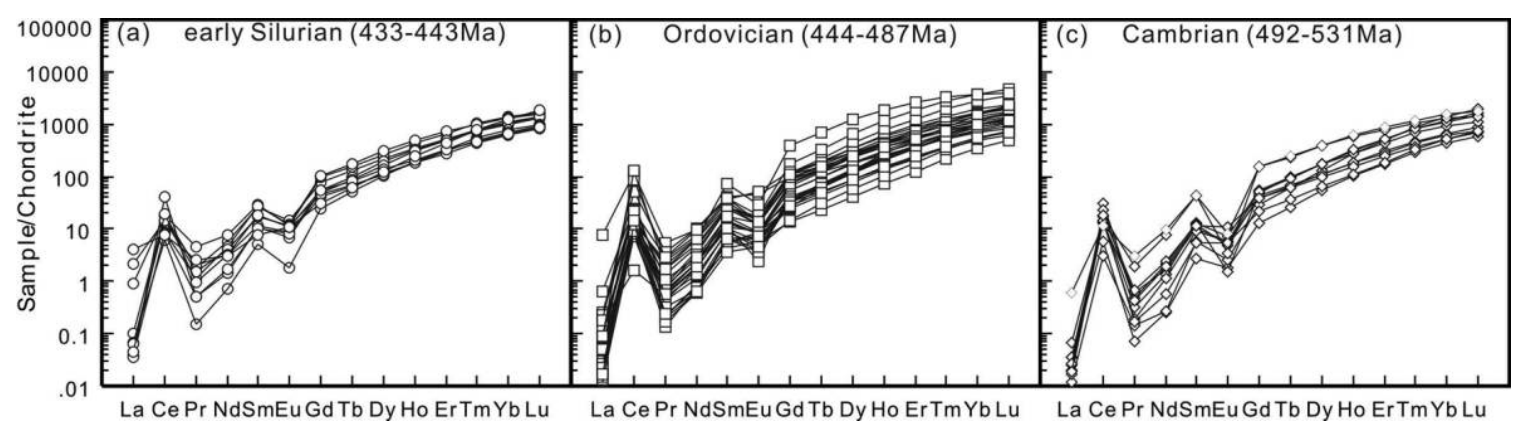

Figure 7. Chondrite-normalized rare earth element (REE) patterns for zircons of 433-443 Ma $(a)$, 444-487 Ma (b), and 492-513 Ma (c). Chondrite REE values are from Taylor and McLennan (1985). 


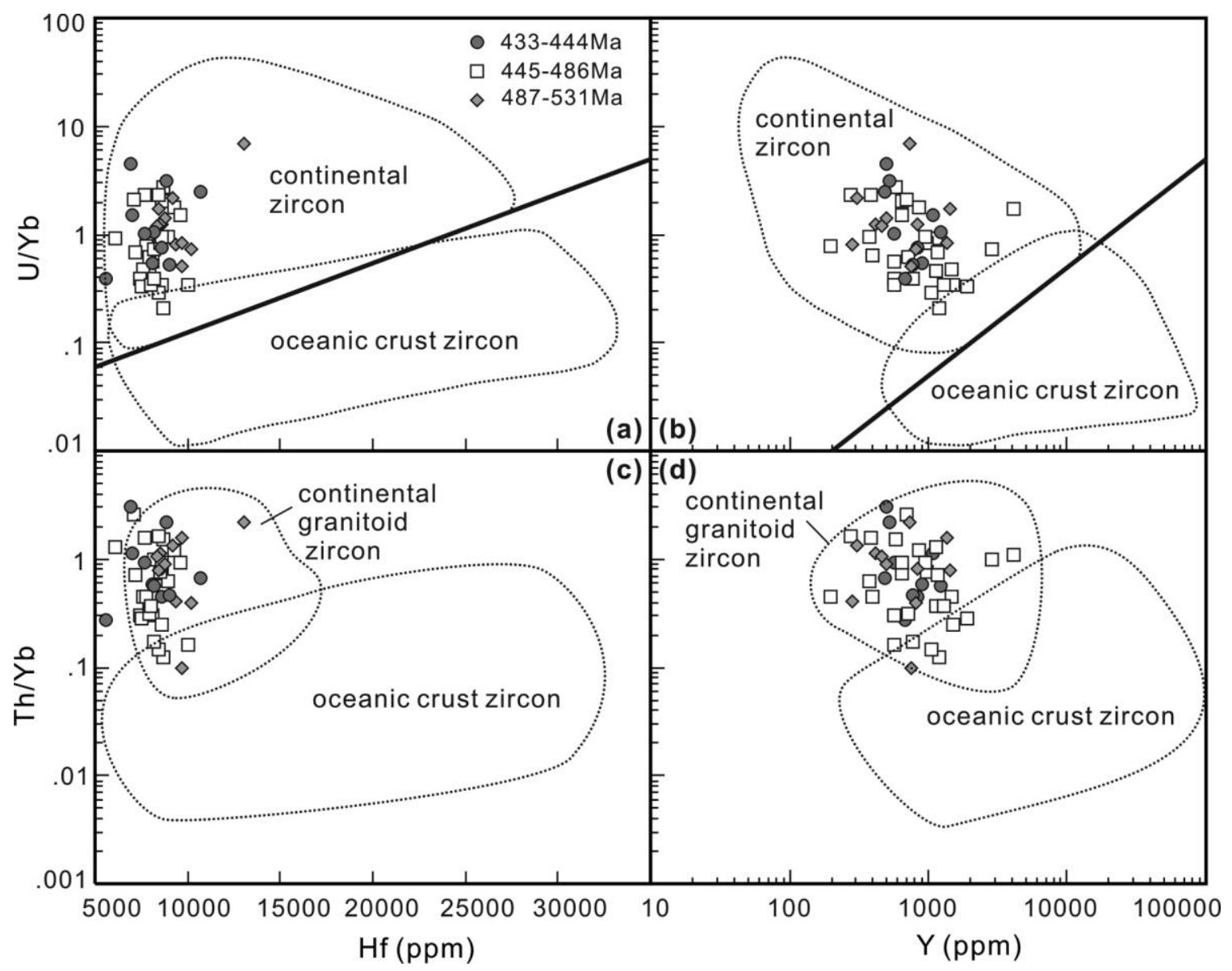

Figure 8. Trace-element discriminating diagrams for the analyzed early Paleozoic zircons: $a, \mathrm{U} / \mathrm{Yb}$ versus Hf; $b, \mathrm{U} /$ $\mathrm{Yb}$ versus $\mathrm{Y} ; c, \mathrm{Th} / \mathrm{Yb}$ versus $\mathrm{Hf}$; and $d, \mathrm{Th} / \mathrm{Yb}$ versus $\mathrm{Y}$. Fields of continental granitoid zircon and oceanic-crust zircon are after Grimes et al. (2007). The solid lines in $a$ and $b$ were redrawn from Grimes et al. (2007) to highlight the lower boundary of the continental zircon field and indicate the upper limit for zircons of unambiguously oceaniccrustal origin.

currence of Cr-spinels (Stevens 1970; Dick and Bullen 1984; Cookenboo et al. 1997; Ganssloser 1999; Hisada et al. 1999; Lee 1999).

The presence of $\mathrm{Cr}$-spinel in sedimentary rocks is generally interpreted as an indicator of ophiolite erosion (Stevens 1970; Pober and Faupl 1988; Cookenboo et al. 1997; Ganssloser 1999; Zhu et al. 2005; Meinhold et al. 2007). In the Qilian Orogen, three potential Cr-spinel sources are present: the Alaskan-type Zhamashi mafic intrusions along the north margin of the Central Qilian Block (Tseng et al. 2009), the Ordovician island-arc basaltic rocks (Hsu and Shau 2002), and the mafic-ultramafic bodies constituting the North Qilian ophiolites (Feng and He 1996; Zhang et al. 1998b; Tseng et al. 2007; Xia and Song 2010). The low $\mathrm{TiO}_{2}$ content, high $\mathrm{Fe}^{2+} / \mathrm{Fe}^{3+}$ ratio, low $\mathrm{Fe}^{3+} \#$ value, and large grain size of the detrital spinels closely match those of spinels from mantle peridotites (fig. $5 a, 5 b$ ) and distinguish them from those hosted by continental flood basalt (CFB), ocean-island basalt (OIB), island-arc basalt (ARC), mid-ocean ridge basalt (MORB), continental mafic-ultramafic intrusions, the Alaskan ultramafic complex, and other unusual rocks such as kimberlites (fig. 5c-5f; Arai 1992; Lenza et al. 2000; Barnes and Roeder 2001; Kamenetsky et al. 2001). Therefore, the only possible spinel source is the ophiolitic rocks in the North Qilian Belt (fig. 3), precluding a derivation from the Zhamashi intrusions (Tseng et al. 2009) or the Ordovician islandarc basaltic rocks (Hsu and Shau 2002).

Potential ophiolitic source rocks within the North Qilian Belt are represented by the Jiugequan, Dachadaban, and Yushigou-Dongcaohe ophiolites, which were emplaced during the Cambrian to Early-Middle Ordovician within/between the back 


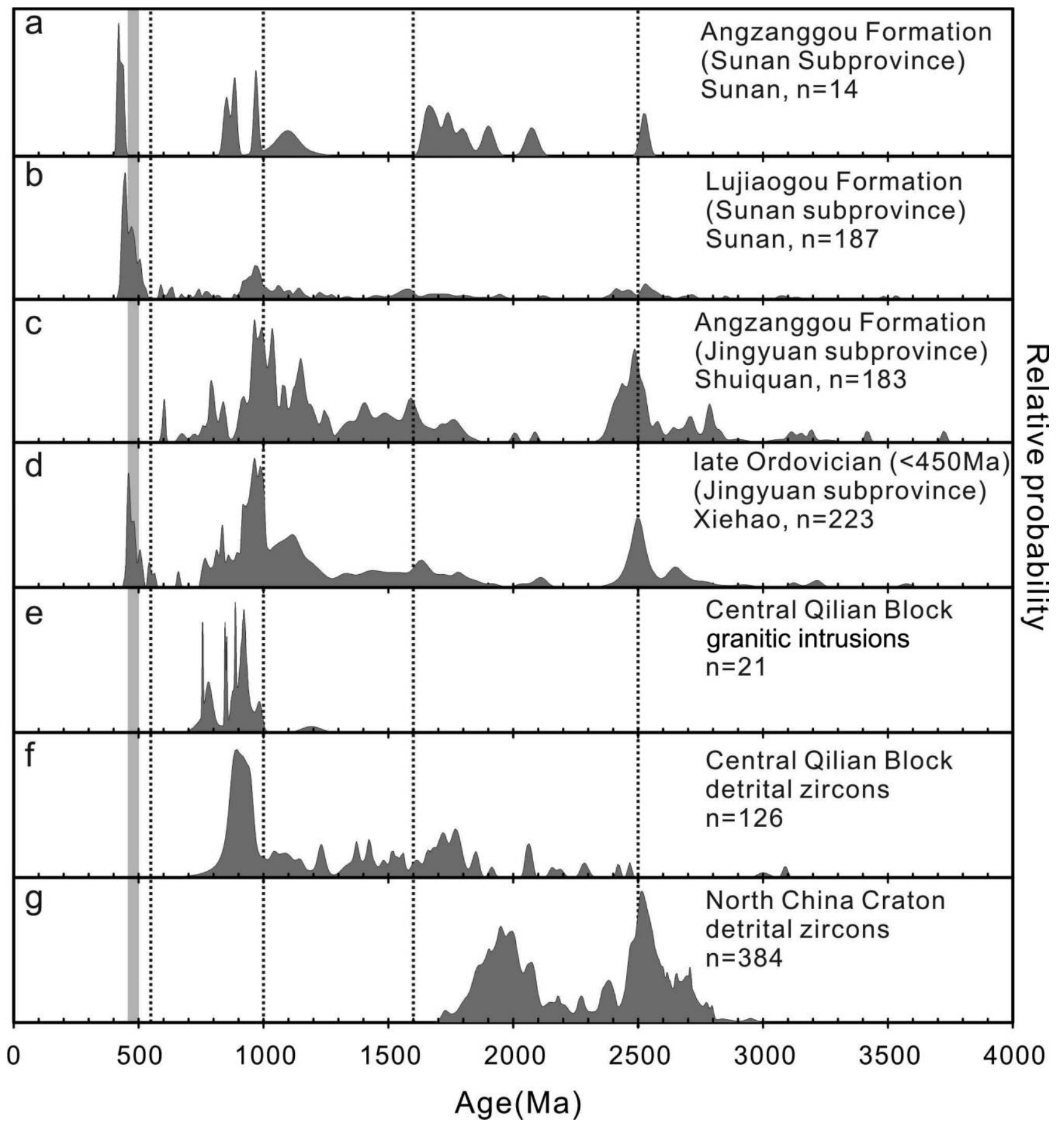

Figure 9. Probability density diagram comparing detrital-zircon ages from the Early Silurian strata in Hexi-Corridor Basin with those of potential source areas. $a$, Early Silurian Angzanggou Formation of Sunan Section, Sunan Subprovince (this study); b, Early Silurian Lujiaogou Formation of Sunan Section, Sunan Subprovince (Yang et al. 2009); c, Early Silurian Angzanggou Formation of Shuiquan Section, Jingyuan Subprovince (Yang et al. 2009); $d$, Late Ordovician sediments of Xiehao Section, Jingyuan Subprovince (Xu et al. 2010); $e$, Central Qilian Block granitic intrusions (Guo et al. 2000; Wan et al. 2000, 2001; Gehrels et al. 2003b; Tung et al. 2007a; Wang et al. 2007; Xu et al. 2007; Yong et al. 2008a; Xue et al. 2009); f, metasedimentary basement of the Central Qilian Block (Gehrels et al. 2003a; Tung et al. 2007a; Xu et al. 2007); $g$, detrital zircons from the basement of the North China Craton (Kröner et al. 1988; Wan et al. 2003; Darby and Gehrels 2006; Tung et al. 2007b; Li et al. 2008). The shaded column represents the age range of the North Qilian magmatic-arc rocks (0.5-0.45 Ga; BGMRQP 1991; Xia et al. 1995; Zhang et al. 1997; Mao et al. 1999, 2000; Xia et al. 2003; Wang et al. 2005a; Chen 2007; Yu et al. 2010). 

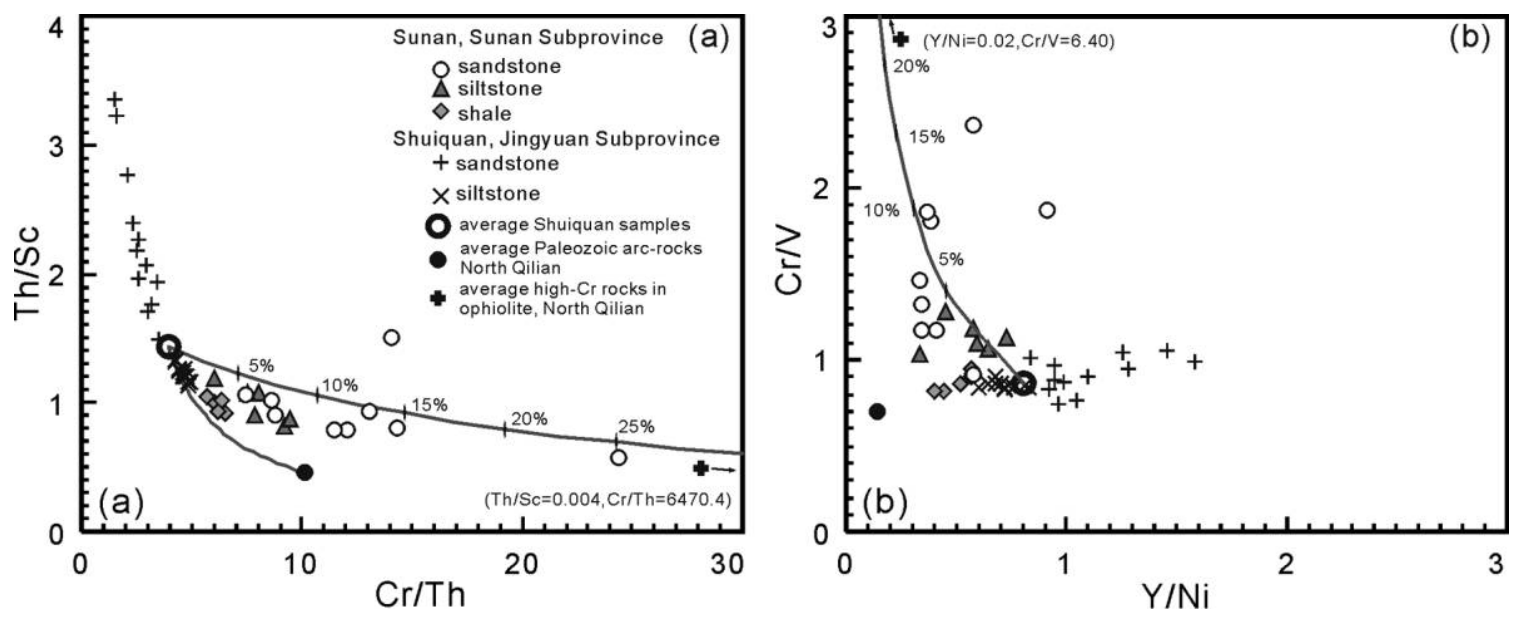

Figure 10. Early Silurian clastic rocks in the North Qilian Belt plotted on $\mathrm{Th} / \mathrm{Sc}$ versus $\mathrm{Cr} / \mathrm{Th}(a)$ and $\mathrm{Cr} / \mathrm{V}$ versus $\mathrm{Y} / \mathrm{Ni}(b)$ diagrams with the average value of the North Qilian magmatic-arc rocks (Xia et al. 2003) and the high-Crcontent rocks of the Dachadaban ophiolite (Chen et al. 1995; Zhang et al. 1998b). The average value of Shuiquan samples, representing the continent provenances (Yang et al. 2009), was calculated with Dachadaban ophioliteprovenance average value to generate two-end-member mixing lines, accounting for the high $\mathrm{Cr} / \mathrm{Th}$ and $\mathrm{Cr} / \mathrm{V}$ ratios of some samples from the Lujiaogou Formation.

arc, the fore-arc complex, and the mid-ocean ridge within the broad suture zone of the North Qilian Belt (Xia et al. 1995; Feng and He 1996; Shi et al. 2004b; Xia and Song 2010). The Cr\# and Ti content of the analyzed detrital spinels from the Lujiaogou Formation are distinct from those of the Dongcaohe ophiolite and equivalent units (fig. 5), which were inferred to represent oceanic lithosphere formed in a mid-ocean ridge setting (Shi et al. 2004b; Tseng et al. 2007).

Of the two remaining ophiolite bodies, the ophiolite in Dachadaban, rather than that in Jiugequan, is considered the more likely source of the Cr-spinel grains, because the former was emplaced south of the early Paleozoic arc terrane, a fore-arc environment (Chen et al. 1995; Feng and He 1996; Zhang et al. 1998b), enabling greater transport and sorting of detritus before deposition than is possible from the Jiugequan ophiolite, which lies to the north of the arc terrane, a back-arc setting (Xia and Song 2010). Pronounced sedimentary recycling could concentrate Cr-spinel relative to unstable lithic fragments and minerals, resulting in the high $\mathrm{Cr} / \mathrm{Ni}$ ratio and the presence of detrital Cr-spinels but also the lack of serpentinite fragments in the studied lower Silurian sandstones (von Eynatten 2003; Yang et al. 2012). Although no corresponding spinel chemical data from the Dachadaban ophiolite are available for comparison, this interpretation is consistent with the studied Cr-spinels falling in the SSZ peridotite field on the $\mathrm{Al}_{2} \mathrm{O}_{3}-\mathrm{TiO}_{2}$ diagram (fig. $5 f$ ), and it is also supported by the $\mathrm{Th} / \mathrm{Sc}-\mathrm{Cr} /$
Th and $\mathrm{Cr} / \mathrm{V}-\mathrm{Y} / \mathrm{Ni}$ plots (fig. 10; McLennan et al. 1993; Totten et al. 2000). On these two diagrams, we performed a two-end-member mixing calculation. We used the average values of Shuiquan samples as the continent-provenance end member (Yang et al. 2012) and the averaged arc rocks south of Sunan County as the arc-provenance end member (Xia et al. 2003). The mixing calculation shows that these two end members cannot by themselves account for the high $\mathrm{Cr} / \mathrm{Th}$ and $\mathrm{Cr} / \mathrm{V}$ ratios of the Sunan clastic rocks (fig. 10). Adding the high-Cr rocks of Dachadaban ophiolite to the continentprovenance end member (Chen et al. 1995; Feng and He 1996; Zhang et al. 1998b) enabled the establishment of a mixing line that matched well the chromium-increasing trend (fig. 10). It is worth stating here that the data presented in this article alone cannot absolutely eliminate the Jiugequan ophiolite as a source.

Given that most zircons formed at mid-ocean ridge (MOR) spreading centers are compositionally distinct from "continental" crustal zircons (Grimes et al. 2007), detrital zircons may be used as a potential provenance indicator for oceanic crust. Trace-element data for the analyzed early Paleozoic zircons mainly plot within the field of continental zircons, with a small proportion of the grains falling in the overlap zone with oceanic-crust zircons (fig. 8). The grains of this small group have $\mathrm{U} / \mathrm{Yb}$ ratios of $0.21-0.35$, slightly higher than those of oceaniccrust zircons analyzed from other regions $(0.18$, on average; Grimes et al. 2007) but much lower than 


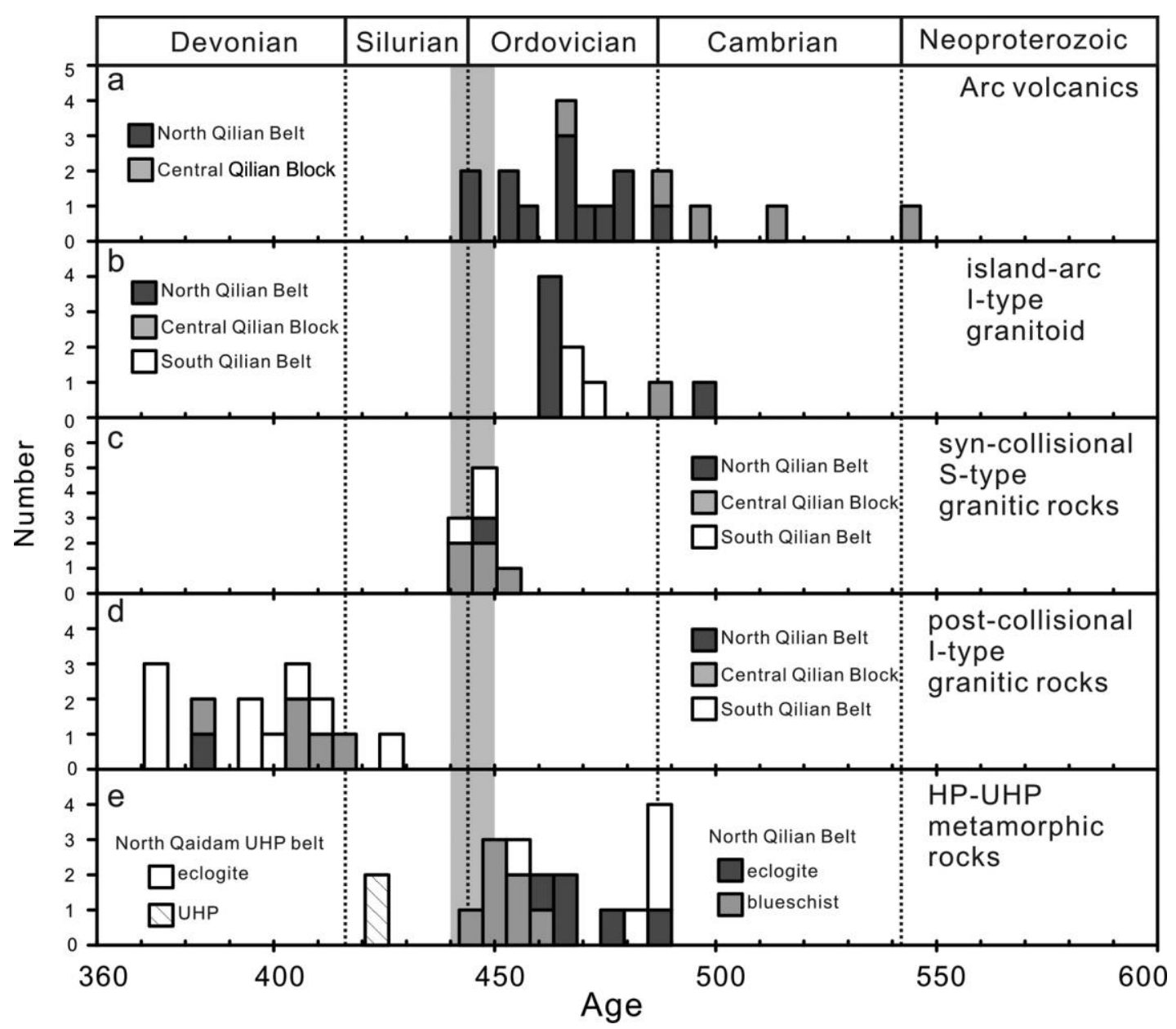

Figure 11. Ages for major units and events related to early Paleozoic orogeny in the Qilian Orogen area. The compiled data include $(a)$ the Sm-Nd isochron ages and zircon U-Pb ages for arc volcanics in the North Qilian Belt (Xia et al. 1995, 2003; Zhang et al. 1997; Wang et al. 2005a; Yu et al. 2010) and the Central Qilian Block (Yuan et al. 2002; Zhao et al. 2003; Shi et al. 2004a; Wang et al. 2005b; Zhu et al. 2010); (b) zircon U-Pb ages (including one Re-Os isochron age) for island-arc I-type granitoids in the North Qilian Belt (BGMRQP 1991; Mao et al. 1999, 2000; Wu et al. 2005; Chen 2007), the Central Qilian Block (Su et al. 2004), and the South Qilian Belt (Wu et al. 2006, 2009); (c) zircon U-Pb ages for syncollisional S-type granitic rocks in the North Qilian Belt (Chen 2007), the Central Qilian Block (BGMRQP 1991; Su et al. 2004; Chen et al. 2008; Yong et al. 2008b), and the South Qilian Belt (Wu et al. 2006, 2007, 2009); (d) zircon U-Pb ages for postcollisional I-type granitic rocks in the North Qilian Belt (plus three Rb-Sr and Re-Os isochron ages; Zhang et al. 1995; Qian et al. 1998; Wu et al. 2005; Liu et al. 2007), the Central Qilian Block (Su et al. 2004), and the South Qilian Belt (Wu et al. 2006, 2007, 2009); and (e) zircon U-Pb ages and Ar-Ar ages for high-ultrahigh-pressure (HP-UHP) metamorphic rocks in the North Qilian Belt and the southern South Qilian Belt (northern Qaidam Belt; Liou et al. 1989; Zhang et al. 1997, 2005, 2007; Song et al. 2004, 2005, 2006; Liu et al. 2006). The shaded column represents the age range (450-440 Ma) at which the Qilian Orogen evolved from oceanic subduction to continental collision.

that of continental granitoid zircons $(1.07$, on average; Grimes et al. 2007). They also have intermediate $\mathrm{Th} / \mathrm{Yb}$ ratios. The slight enrichment in $\mathrm{Th}$ and $U$ suggests a subduction-related setting for the crystallization of these zircons (Grimes et al. 2007). Overall, however, the early Paleozoic zircon trace elements argue for a continental source, possibly formed in an arc-related setting (Grimes et al.
2007). An unambiguous oceanic-crust provenance for zircons was not detected. Considering that the field of oceanic-crust zircon was defined by grains from the MOR igneous rocks (Grimes et al. 2007), this result is coincident with that of the detrital Cr-spinel data, which also negate a derivation from a MOR-type ophiolite (see above). Notably, the continent-arc and some island-arc rocks have zircon 
(a) $>550-450 \mathrm{Ma}$

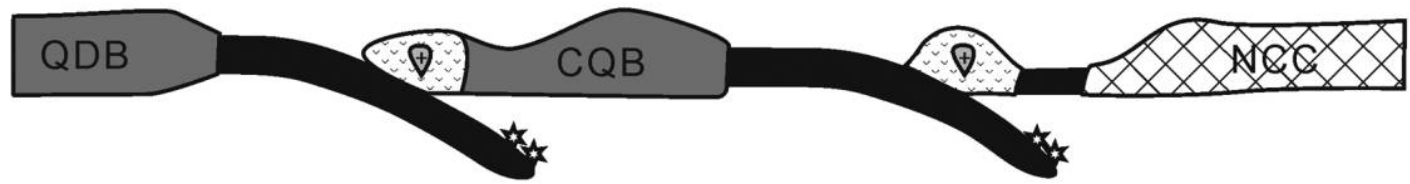

(b) $450-440 \mathrm{Ma}$

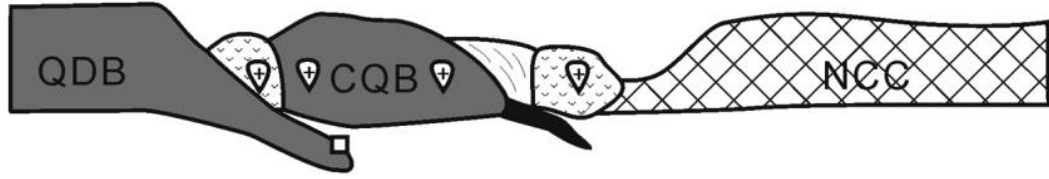

$\rightarrow \begin{gathered}\text { island-arc } \\ \text { I-type } \\ \text { granitoids } \\ \text { syn-collisional }\end{gathered}$

(c) Lujiaogou Formation ( 435 Ma)

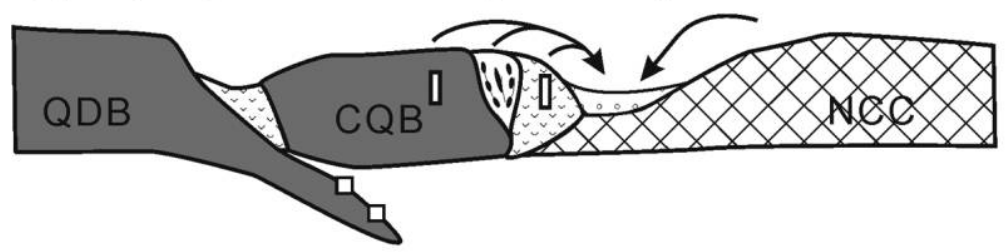

(d) Angzanggou Formation

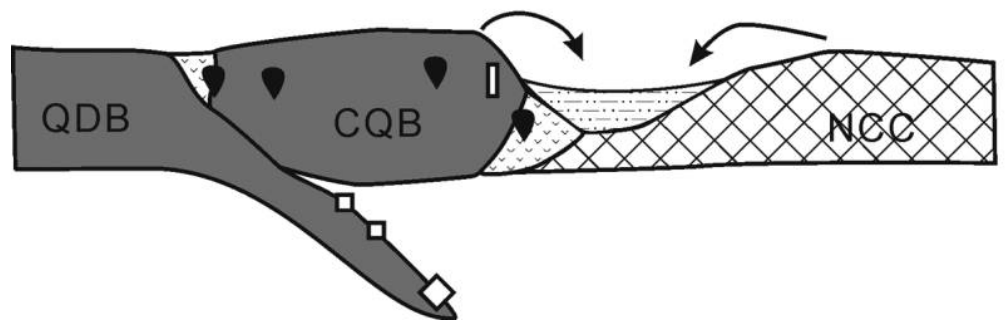

$\oplus \quad$ S-type

granitic rocks post-collisional

I I-type granitic rocks

n mafic intrusion /volcanics

eclogite-

* metamorphism

nP granulite metamorphsim

$\diamond$ UHP metamorphism

Figure 12. Model of the tectonic transformation of the North Qilian Orogen from oceanic subduction to continental collision as well as the associated magmatic, metamorphic, and sedimentary events. $a$, Subduction of the South and North Qilian oceans (>550-450 Ma) and accompanying arc volcanism, island-arc I-type granitic intrusions, and eclogite (blueschist)-facies metamorphism. $b$, Ocean closure and initiation of continental collision accompanied by syncollisional S-type granitic intrusions and high-pressure (HP) granulite metamorphism (450-440 Ma). $c$, Erosion of the Central Qilian Block and the volcanic-arc and the uplifted ophiolites within the suture zone of the North Qilian Belt during the deposition of the Lujiaogou Formation, accompanied by high-medium-pressure granulite metamorphism and mafic intrusions. $d$, Rapid uplift and thrusting of the Central Qilian Block resulting in the rapid influx of debris from this source into the foreland basin during the deposition of Angzanggou Formation, accompanied by ultrahighpressure (UHP) metamorphism, mafic intrusions, and postcollisional I-type granitic rocks. QDB = Qaidam Block; $\mathrm{CQB}=$ Central Qilian Block; NCC = North China Craton.

fields overlapping those of the continental granitoids (Grimes et al. 2007). Thus, a possible explanation is that some zircons may be dispersed from an SSZ ophiolitic provenance in the same way as the Cr-spinels but exhibit chemical characters that distinguish them from those in MOR rocks but are similar to those in subduction-related rocks. Another explanation is that an ophiolitic source consisting mainly of mafic and ultramafic rocks will not yield many, if any, zircons, and so MOR-like zircons were simply not analyzed.
Tectonic Transformation. In the North Qilian Belt, the Yushigou-Dongcaohe ophiolite belt is dated at 550-497 Ma and has a MORB-type geochemical signature (Feng and He 1996; Shi et al. 2004b; Tseng et al. 2007). The lavas are overlain by radiolarian cherts and are interpreted to represent a fragment of the North Qilian oceanic basement that lay between the continental Central Qilian Block and the North China Craton (Xia et al. 1995; Shi et al. 2004b). Subduction of the North Qilian Ocean beneath the south margin of the North 
China Craton to form the North Qilian Belt is inferred to have begun at the beginning of the Ordovician, on the basis of arc-related volcanic rocks ranging in age from 486 to $446 \mathrm{Ma}$ (Xu et al. 1994; Xia et al. 1995, 2003; Feng and He 1996; Zhang et al. 1997; Wang et al. 2005a; Yu et al. 2010), islandarc I-type granitoids dated at 495-460 $\mathrm{Ma}$ (BGMRQP 1991; Mao et al. 1999, 2000; Chen 2007), and eclogite-blueschist facies metamorphic rocks with SHRIMP zircon ages of 489-463 Ma and ArAr ages of 462-448 Ma (Liou et al. 1989; Zhang et al. 1997, 2007; Song et al. 2004, 2009; Liu et al. 2006; fig. 11).

The Hexi-Corridor Basin, in which the analyzed Silurian samples occur, lies between the arc volcanic rocks and the North China Craton. It was initiated in the Early Ordovician as a back-arc basin (Xu et al. 1994; Xia et al. 2003). The presence of detrital-zircon grains as young as $\sim 435 \mathrm{Ma}$ and of ophiolite-derived Cr-spinel in the lower Silurian Lujiaogou Formation of Sunan Subprovince within the basin suggests that this unit was receiving material from syndepositional igneous activity related to erosion of the island arc (fig. 12). The presence of Precambrian grains within the unit derived from the Central Qilian Block and the North China Craton, with the former lying to the south of the North Qilian Ocean, suggests that this unit approximates the timing of ocean closure and collisional suturing of the two continental fragments. A similar age pattern of detritus was reported for the Late Ordovician sediments within the Jingyuan Subprovince, which were deposited after $450 \mathrm{Ma}$ (Xu et al. 2010). These relationships are consistent with the presence of syncollisional S-type granite dated at $447 \pm 3.6 \mathrm{Ma}$ within the North Qilian Belt (Chen 2007), suggesting that the continental collision initiated after the ocean closure by the end of the Ordovician.

In the regional context, all three units of the Qilian Orogen (north, central, and south) display evidence for syncollisional S-type granitic magmatism during the Late Ordovician-Early Silurian (BGMRQP 1991; Su et al. 2004; Wu et al. 2006, 2007, 2009; Chen 2007; Chen et al. 2008; Yong et al. 2008b), which is related to the collision between the Qaidam Block, the Central Qilian Block, and the North China Craton. They are all dated in the range 450-440 Ma, which postdates the arc volcanism, island-arc I-type granitoids (Yuan et al. 2002;
Zhao et al. 2003; Shi et al. 2004a; Wang et al. 2005b; Zhu et al. 2010), and oceanic subduction-induced eclogite-facies metamorphism (Song et al. 2004, 2006; Zhang et al. 2005, 2007) but predates the postcollisional I-type granitic magmatism (Zhang et al. 1995; Qian et al. 1998; Wu et al. 2005; Liu et al. 2007) and continental subduction-induced North Qaidam UHP metamorphism (Song et al. 2005, 2006; figs. 2, 11). The high-pressure granulitefacies metamorphism at about $450 \mathrm{Ma}$ in the southern South Qilian Belt is interpreted to be related to the early Paleozoic continental collision between the Qaidam and Central Qilian blocks (Zhang et al. 2008a). The ca. 445-434-Ma northwest-southeast-trending mafic volcanics and mafic dikes in the Central Qilian and North Qilian belts were also considered to be consequences of the southwestnortheast compression and contraction induced by continental collision (Xia et al. 1995; Chen et al. 2006; He et al. 2007). The $P$-T paths of eclogite and blueschist assemblages reflect a process by which the protoliths underwent deep burial to reach peak metamorphism during oceanic subduction before ca. $443 \mathrm{Ma}$ and then experienced uplift and erosion during the mountain building of the Qilian Orogen (Chen et al. 2002). These data indicate that the switch from oceanic subduction to continental collision and orogenesis for the whole Qilian Orogen occurred in the Late Ordovician-Early Silurian, about $450-440 \mathrm{Ma}$ (fig. 12). The timing of collisional suturing within the Qilian Orogen corresponds to, and may have contributed to, the documented widespread regional uplift across the North China Craton (Liu et al. 1999; Wang et al. 2010).

\section{A C K N O W L E D G M E N T S}

We are grateful to Y. S. Liu, Z. Hu, and S. Zheng of China University of Geosciences (Wuhan) for their help with LA-ICPMS and electron microprobe analyses. Y. Wu of China University of Geosciences (Wuhan) provided constructive comments on an earlier draft of the manuscript. The editor and reviewers are thanked for their help with clarifying the ideas and interpreting the data presented in the manuscript. This research is supported by the National Natural Science Foundation of China (40672080, 40921062) and the 111 Project (grant B08030). 


\section{R E F E R E N C E S C I T E D}

Arai, S. 1992. Chemistry of chromian spinel in volcanic rocks as a potential guide to magma chemistry. Mineral. Mag. 56:176-184.

Arai, S., and Okada, H. 1991. Petrology of serpentine sandstone as a key to tectonic development of serpentine belts. Tectonophysics 195:65-81.

Barnes, S. J., and Roeder, P. L. 2001. The range of spinel compositions in terrestrial mafic and ultramafic rocks. J. Petrol. 42:2279-2302.

BGMRGP (Bureau of Geology and Mineral Resources of Gansu Province). 1989. Regional geology of Gansu Province. Beijing: Geological Publishing House, 690 p. (in Chinese with English abstract).

BGMRQP (Bureau of Geology and Mineral Resources of Qinghai Province). 1991. Regional geology of Qinghai Province. Beijing: Geological Publishing House, 603 p. (in Chinese with English abstract).

Bian, Q.; Gao, S.; Li, D.; Ye, Z.; Chang, C.; and Luo X. 2001. A study of the Kunlun-Qilian-Qinling Suture System. Acta Geol. Sin. 75:364-374.

Chen, H. 2007. Geochemistry features of Ningchanhe granite body and its tectonic significance in Lenglongling of North Qilian. Gansu Geol. 16(4):37-42 (in Chinese with English abstract).

Chen, J.; He, S.; Wang, H.; Xu, X.; Zeng, Z.; Wang, Z.; and Yan, Q. 2006. Zircon LA-ICPMS U-Pb age of magic dykes in the area between the Qinling and the Qilian orogenic belts and its geological implications. Acta Petrol. Mineral. 25:455-462 (in Chinese with English abstract).

Chen, J. B.; Wu, T. S.; Zhang, P. Y.; and You, W. C. 1997. Regional stratigraphy of North China. Wuhan: China University of Geosciences Press, 199 p.

Chen, J. L.; Xu, X. Y.; Zeng, Z. X.; Xiao, L.; Wang, H. L.; Wang, Z. Q.; and Xiao, S. W. 2008. Geochemical characters and LA-ICPMS zircon dating constraints on the petrogenesis and tectonic setting of the Shichuan intrusion, east segment of the central Qilian, NW China. Acta Petrol. Sin. 24:841-854 (in Chinese with English abstract).

Chen, W. M.; Huang, Y. C.; Yoshiyuki, I.; Lo, C. H.; Wu, H.; Song, S.; Yang, J.; Xu, Z.; and Yang, H. Y. 2002. Integrated $P-T$ paths of the high-pressure rocks and their tectonic implications for the mountain-building of the North Qilian, China. Acta Geol. Sin. 76:44-62.

Chen, Y.; Zhou, D.; Wang, E.; and Li, X. 1995. Geochemical characteristics of bonitite series rocks found in Dachadaban Ophiolite (DDO), Sunan County, North Qilian Mountain. Acta Petrol. Sin. 11(suppl.):147-153 (in Chinese with English abstract).

Chutakositkanon, V.; Hisada, K. I.; Charusiri, P.; and Arai, S. 2001. Tectonic significance of detrital chromian spinels in the Permian Nam Duk Formation, central Thailand. Geosci. J. 5:89-96.

Cookenboo, H. O.; Bustin, R. M.; and Wilks, K. R. 1997.
Detrital chromian spinel compositions used to reconstruct the tectonic setting of provenance: implications for orogeny in the Canadian Cordillera. J. Sediment. Res. 67:116-123.

Darby, B. J., and Gehrels, G. 2006. Detrital zircon reference for the North China Block. J. Asian Earth Sci. 26:637-648.

de Jong, K.; Xiao, W.; Windley, B. F.; Masago, H.; and Lo, C. H. 2006. Ordovician ${ }^{40} \mathrm{Ar} /{ }^{39} \mathrm{Ar}$ phengite ages from the blueschist-facies Ondor Sum subduction-accretion complex (Inner Mongolia) and implications for the early Paleozoic history of continental blocks in China and adjacent areas. Am. J. Sci. 306:799-845.

Dick, H. J. B., and Bullen, T. 1984. Chromian spinel as a petrogenetic indicator in abyssal and alpine-type peridotites and spatially associated lavas. Contrib. Mineral. Petrol. 86:54-76.

Du, Y.; Wang, J.; and Han, X. 2003. From flysch to molasse: sedimentary and tectonic evolution of Late Caledonian-Early Hercynian foreland basin in North Qilian Mountains. J. China Univ. Geosci. 14:1-7.

Du, Y.; Zhu, J.; Gu, S.; Xu, Y.; and Yang, J. 2007. Sedimentary geochemistry of the Cambrian-Ordovician cherts: implication on archipelagic ocean of North Qilian Orogenic Belt. Sci. China (Ser. D) 50:1628-1644.

Du, Y.; Zhu, J.; Han, X.; and Gu, S. 2004. From the backarc basin to foreland basin: Ordovician-Devonian sedimentary basin and tectonic evolution in the North Qilian orogenic belt. Geol. Bull. China 23:911-917 (in Chinese with English abstract).

Fan, G., and Lei, D. 2007. Precise timing of Caledonian structural deformation chronology and its implications in southeast Qilian Mountains, China. J. China Univ. Geosci. 18:11-18.

Feng, Y., and He, S. 1996. Geotectonics and orogeny of the Qilian Mountains, China. Beijing: Geological Publishing House, 135 p. (in Chinese).

Ganssloser, M. 1999. Detrital chromian spinel in Rhenohercynian greywackes and sandstones (GivetianVisean, Variscides, Germany) as indicators of ultramafic source rocks. Geol. Mag. 136:437-451.

Garver, J. I.; Royce, P. R.; and Smick, T. A. 1996. Chromium and nickel in shale of the Taconic foreland: a case study for the provenance of fine-grained sediments with an ultramafic source. J. Sediment. Res. 66: 100-106.

Garver, J. I., and Scott, T. J. 1995. Trace elements in shale as indicators of crustal provenance and terrane accretion in the southern Canadian Cordillera. Geol. Soc. Am. Bull. 107:440-453.

Gehrels, G. E.; Yin, A.; and Wang, X. F. 2003a. Detritalzircon geochronology of the northeastern Tibetan Plateau. Geol. Soc. Am. Bull. 115:881-896.

Gehrels, G. E.; Yin, A.; and Xiao, X. F. 2003b. Magmatic 
history of the northeastern Tibetan Plateau. J. Geophys. Res. 108(B9):2423-2436.

Grimes, C. B.; John, B. E.; Kelemen, P. B.; Mazdab, F. K.; Wooden, J. L.; Cheadle, M. J.; and Schwartz, J. J. 2007. Trace element chemistry of zircons from oceanic crust: a method for distinguishing detrital zircon provenance. Geology 35:643-646.

Guo, J.; Zhao, F.; Li, H.; Li, H.; and Zuo, Y. 2000. New chronological evidence of the age of Huangyuan Group in the eastern segment of Mid-Qilian massif and its geological significance. Reg. Geol. China 19: 26-31 (in Chinese with English abstract).

He, S.; Wang, H.; Chen, J.; Xu, X.; Zhang, H.; Ren, G.; and $\mathrm{Yu}, \mathrm{J}$. 2007. LA-ICP-MS U-Pb zircon geochronology of basic dikes within Maxianshan Rock Group in the Central Qilian Orogenic Belt and its tectonic implication. J. China Univ. Geosci. 18:19-29.

Hisada, K. I.; Arai, S.; and Lee, Y. I. 1999. Tectonic implication of lower Cretaceous chromian spinel-bearing sandstones in Japan and Korea. Isl. Arc 8:336-348.

Hiscott, R. N. 1984. Ophiolitic source rocks for Taconicage flysch: trace-element evidence. Geol. Soc. Am. Bull. 95:1261-1267.

Hoskin, P. W. O., and Ireland, T. R. 2000. Rare earth element chemistry of zircon and its use as a provenance indicator. Geology 28:627-630.

Hoskin, P. W. O., and Schaltegger, U. 2003. The composition of zircon and igneous and metamorphic petrogenesis. In Hanchar, J. M., and Hoskin, P. W. O., eds. Zircon. Rev. Mineral. Geochem. 53:27-64.

Hsu, T. W., and Shau, Y. H. 2002. A petrographic and mineralogical study of volcanic rocks from the Mayaxueshan area, North Qilian Fold Belt, NW China. Acta Geol. Sin. 76:15-30.

Kamenetsky, V. S.; Crawford, A. J.; and Meffre, S. 2001. Factors controlling chemistry of magmatic spinel: an empirical study of associated olivine, Cr-spinel and melt inclusions from primitive rocks. J. Petrol. 42: 655-671.

Kröner, A.; Compston, W.; Zhang, G.; Guo, A.; and Todt, W. 1988. Age and tectonic setting of late Archean greenstone-gneiss terrain in Henan Province, China, as revealed by single-grain zircon dating. Geology 16: 211-215.

Kusky, T. M.; Windley, B. F.; and Zhai, M.-G. 2007. Tectonic evolution of the North China Block: from orogen to craton to orogen. In Zhai, M.-G.; Windley, B. F.; Kusky, T. M.; and Meng, Q. R., eds. Mesozoic subcontinental lithospheric thinning under eastern Asia. Geol. Soc. Lond. Spec. Publ. 280:1-34.

Lee, Y. I. 1999. Geotectonic significance of detrital chromian spinel: a review. Geosci. J. 3:23-29.

Lenza, D.; Kamenetsky, V. S.; Crawford, A. J.; and Princivalle, F. 2000. Melt inclusions in detrital spinel from the SE Alps (Italy-Slovenia): a new approach to provenance studies of sedimentary basins. Contrib. Mineral. Petrol. 139:748-758.

Li, Q.; Liu, S.; Wang, Z.; Chu, Z.; Song, B.; and Wang, Y. 2008. Contrasting provenance of late Archean metasedimentary rocks from the Wutai Complex, North
China Craton: detrital zircon U-Pb, whole-rock Sm$\mathrm{Nd}$ isotopic, and geochemical data. Int. J. Earth Sci. 97:443-458.

Liou, J. G.; Wang, X. M.; and Coleman, R. G. 1989. Blueschists in major suture zones of China. Tectonics 8: 609-619.

Liu, B.; Qian, X., and Wang, Y. 1999. Tectono-sedimentary evolution of North China Plate in early Paleozoic. Sci. Geol. Sin. 34:347-356 (in Chinese with English abstract).

Liu, X. H.; Sun, B. N.; Qu, W. J.; Kang, H. J.; and Wu, J. Y. 2007. Re-Os dating of molybdenite in Xiliugou WMo deposit in western part of north Qilian Mountains and its geological significance. Acta Petrol. Sin. 23: 2434-2442 (in Chinese with English abstract).

Liu, Y. J.; Neubauer, F.; Genser, J.; Takasu, A.; Ge, X. H.; and Handler, R. 2006. ${ }^{40} \mathrm{Ar} /{ }^{39} \mathrm{Ar}$ ages of blueschist facies pelitic schists from Qingshuigou in the northern Qilian Mountains, western China. Isl. Arc 15:187198.

Liu, Y. S.; Hu, Z.; Gao, S.; Günther, D.; Xu, J.; Gao, C.; and Chen, H. 2008. In situ analysis of major and trace elements of anhydrous minerals by LA-ICP-MS without applying an internal standard. Chem. Geol. 257: 34-43.

Ludwig, K. R. 2003. User's manual for ISOPLOT 3.00: a geochronological toolkit for Microsoft Excel. Spec. Publ. 4. Berkeley, CA, Berkeley Geochronology Center.

Mao, J.; Zhang, Z.; Jian, P.; Zhang, Z.; Yang, J.; and Zhang, Z. 2000. U-Pb zircon dating of the Yeniutan granitic intrusion in the western sector of the North Qilian Mountains. Acta Geol. Sin. 74:781-785.

Mao, J.; Zhang, Z.; Zhang, Z.; and Du, A. 1999. Re-Os isotopic dating of molybdenites in Xiaoliugou $\mathrm{W}(\mathrm{Mo})$ deposit in the northern Qilian Mountains and its geological significance. Geochim. Cosmochim. Acta 63: 1815-1818.

McLennan, S. M.; Heming, S.; McDaniel, D. K.; and Hanson, G. N. 1993. Geochemical approaches to sedimentation, provenance, and tectonics. In Johnsson, $\mathrm{M}$. J., and Basu, A., eds. Processes controlling the composition of clastic sediments. Geol. Soc. Am. Spec. Pap. 284:21-40.

Meinhold, G.; Kostopoulos, D.; and Reischmann, T. 2007. Geochemical constraints on the provenance and depositional setting of sedimentary rocks from the islands of Chios, Inousses and Psara, Aegean Sea, Greece: implications for the evolution of Paleotethys. J. Geol. Soc. Lond. 164:1145-1163.

Pober, E., and Faupl, P. 1988. The chemistry of detrital chromian spinel and its implications for the geodynamic evolution of the eastern Alps. Geol. Rundsch. 77:641-670.

Preston, J.; Hartley, A.; Mange-Rajetzky, M.; Hole, M.; May, G.; and Buck, S. 2002. The provenance of Triassic continental sandstones from the Beryl Field, northern North Sea: mineralogical, geochemical, and sedimentological constraints. J. Sediment. Res. 72:18-29.

Qian, Q.; Wang, Y.; Li, H.; Jia, X.; Han, S.; and Zhang, Q. 
1998. Geochemical characteristics and genesis of diorites from Laohushan, Gansu Province. Acta Petrol. Sin. 14:520-528 (in Chinese with English abstract).

Qian, Q.; Zhang, Q.; and Wang, Y. 2001. Early Paleozoic North Qilian oceanic basin, an analogue to modern west Pacific: evidence from geochemical characteristics of ophiolites. InterRidge News 10:28-31.

Regional Geological Surveying Team. 1986. The Silurian system in Gansu Province. Gansu Geol. 3:1-117 (in Chinese with English abstract).

Shi, R.; Yang, J.; Wu, C.; Tsuyoshi, I.; and Takafumi, H. $2004 a$. Island arc volcanic rocks in the North Qaidam UHP metamorphic belt. Acta Geol. Sin. 78:52-64 (in Chinese with English abstract).

Shi, R.; Yang, J.; Wu, C.; and Wooden, J. 2004b. First SHRIMP dating for the formation of the late Sinian Yushigou Ophiolite, North Qilian Mountains. Acta Geol. Sin. 78:649-657 (in Chinese with English abstract).

Smith, A. D. 2006. The geochemistry and age of ophiolitic strata of the Xinglongshan Group: implications for the amalgamation of the Central Qilian Belt. J. Asian Earth Sci. 28:133-142.

Song, S.; Niu, Y.; Zhang, L.; Wei, C.; Liou, J. G.; and Su, L. 2009. Tectonic evolution of early Paleozoic HP metamorphic rocks in the North Qilian Mountains, NW China: new perspectives. J. Asian Earth Sci. 35: 334-353.

Song, S.; Zhang, L.; Niu, Y.; Li, S.; Song, B.; and Liu, D. 2006. Evolution from oceanic subduction to continental collision: a case study from the northern Tibetan Plateau based on geochemical and geochronological data. J. Petrol. 47:435-455.

Song, S.; Zhang, L.; Niu, Y.; Song, B.; Zhang, G.; and Wang, Q. 2004. Zircon U-Pb SHRIMP ages of eclogites from the North Qilian Mountains in NW China and their tectonic implication. Chin. Sci. Bull. 49:848852.

Song, S.; Zhang, L.; Niu, Y.; Su, L.; Jian, P.; and Liu, D. 2005. Geochronology of diamond-bearing zircons from garnet peridotite in the North Qaidam UHP belt, North Tibetan Plateau: a record of complex histories from oceanic lithosphere subduction to continental collision. Earth Planet. Sci. Lett. 234:99-118.

Stevens, R. K. 1970. Cambro-Ordovician flysch sedimentation and tectonics in west Newfoundland and their possible bearing on a Proto-Atlantic Ocean. In Lajoie, J., ed. Flysch sedimentology in North America. Geol. Assoc. Can. Spec. Pap. 7:165-177.

Su, J.; Hu, N.; Zhang, H.; and Feng, B. 2004. U-Pb dating and genesis of the Heigouliangzi granitic intrusion in the western segment of the middle Qilian Mountains. Geoscience 18:70-74 (in Chinese with English abstract).

Taylor, S. R., and McLennan, S. M. 1985. The continental crust: its composition and evolution. Oxford, Blackwell, $312 \mathrm{p}$.

Totten, M. W.; Hanan, M. A.; and Weaver, B. L. 2000. Beyond whole-rock geochemistry of shales: the im- portance of assessing mineralogic controls for revealing tectonic discriminants of multiple sediment sources for the Ouachita Mountain flysch deposits. Geol. Soc. Am. Bull. 112:1012-1022.

Tseng, C.; Yang, H.; Yang, H.; Liu, D.; Tsai, C.; Wu, H.; and Zuo, G. 2007. The Dongcaohe ophiolite from the North Qilian Mountains: a fossil oceanic crust of the Paleo-Qilian Ocean. Chin. Sci. Bull. 52:2390-2401.

Tseng, C. Y.; Zuo, G. C.; Yang, H. J.; Yang, H. Y.; Tung, K. A.; Liu, D. Y.; and Wu, H. Q. 2009. Occurrence of Alaskan-type mafic-ultramafic intrusions in the North Qilian Mountains, northwest China: evidence of Cambrian arc magmatism on the Qilian Block. Isl. Arc 18:526-549.

Tung, K. A.; Yang, H.-J.; Yang, H.-Y.; Liu, D. Y.; Zhang, J. X.; Wan, Y. S.; and Tseng, C.-Y. 2007a. Shrimp U$\mathrm{Pb}$ geochronology of the zircon from the Precambrian basement of the Qilian Block and its geological significances. Chin. Sci. Bull. 52:2687-2701.

Tung, K. A.; Yang, H. Y.; Liu, D. Y.; Zhang, J. X.; Tseng, C. Y.; and Wan, Y. S. 2007b. SHRIMP U-Pb geochronology of the detrital zircons from the Longshoushan Group and its tectonic significance. Chin. Sci. Bull. 52:1414-1426.

von Eynatten, H. 2003. Petrography and chemistry of sandstones from the Swiss Molasse Basin: an archive of the Oligocene to Miocene evolution of the central Alps. Sedimentology 50:703-724.

Wan, Y.; Xu, Z.; Yang, J.; and Zhang, J. 2001. Ages and composition of the Precambrian high-grade basement of the Qilian terrane and its adjacent areas. Acta Geol. Sin. 75:375-384.

Wan, Y.; Yang, J.; Xu, Z.; and Wu, C. 2000. Geochemical characteristics of the Maxianshan Complex and Xinglong Group in the eastern segment of the Qilian Orogen Belt. J. Geol. Soc. China 43:52-68.

Wan, Y.; Zhang, J.; Yang, J.; and Xu, Z. 2006. Geochemistry of high-grade metamorphic rocks of the North Qaidam Mountains and their geological significance. J. Asian Earth Sci. 28:174-184.

Wan, Y.; Zhang, Q.; and Song, T. 2003. SHRIMP ages of detrital zircons from the Changcheng system in the Ming Tembs area, Beijing: constraints on the protolith nature and maximum depositional age of the Mesoproterozoic cover of the North China Craton. Chin. Sci. Bull. 48:2500-2506.

Wang, C. Y.; Zhang, Q.; Qian, Q.; and Zhou, M. F. $2005 a$. Geochemistry of the early Paleozoic Baiyin volcanic rocks (NW China): implications for the tectonic evolution of the North Qilian orogenic belt. J. Geol. 113: 83-94.

Wang, H.; He, S.; Chen, J.; Xu, X.; Sun, Y.; and DiWu, C. 2007. LA-ICPMS dating of zircon U-Pb and its tectonic significance of Maxianshan granitoid intrusive complex, Gansu Province. Acta Geol. Sin. 81:72-78 (in Chinese with English abstract).

Wang, H.; Lu, S.; Mo, X.; Li, H.; and Xin, H. 2005b. Early Paleozoic collisional orogen on the northern margin of the Qaidam Basin, northwestern China. Geol. Bull. China 24:603-612 (in Chinese with English abstract). 
Wang, Y.; Zhou, L.; Zhao, L.; Ji, M.; and Gao, H. 2010. Palaeozoic uplands and unconformity in the North Block: constraints from zircon LA-ICP-MS dating and geochemical analysis of bauxite. Terra Nova 22:264273.

Wilde, S. A.; Cawood, P. A.; Wang, K. Y.; Nemchin, A. A.; and Zhao, G. 2004. Determining Precambrian crustal evolution in China: a case study from Wutaishan, Shanxi Province, demonstrating the applications of precise SHRIMP U-Pb geochronology. In Malpas, J.; Fletcher, C. J. N.; Ali, J. R.; and Aitchison, J. C., eds. Aspects of the tectonic evolution of China. Geol. Soc. Lond. Spec. Publ. 226:5-26.

Wu, C.; Gao, Y.; Wu, S.; Chen, Q.; Wooden, J. L.; Mazdab, F. K.; and Mattinson, C. 2007. Zircon SHRIMP U-Pb dating of granites from the Da Qaidam area in the north margin of Qaidam Basin, NW China. Acta Petrol. Sin. 23:1861-1875 (in Chinese with English abstract).

Wu, C.; Shi, R.; Yang, J.; Yang, H.; Wooden, J. L.; Zheng, Q.; and Cheng, S. 2005. Petrogenesis and dating of two types of granite from North Qilian, China. Acta Geol. Sin. 79:193-200.

Wu, C.; Wooden, J. L.; Robinson, P. T.; Gao, Y.; Wu, S.; Chen, Q.; Mazdab, F. K.; and Mattinson, C. 2009. Geochemistry and zircon SHRIMP U-Pb dating of granitoids from the west segment of the North Qaidam. Sci. China (Ser. D) 52:1771-1790.

Wu, C.; Wooden, J. L.; Yang, J.; Robinson, R. T.; Zheng, L.; Shi, R.; and Chen, S. 2006. Granitic magmatism in the North Qaidam early Paleozoic ultrahigh-pressure metamorphic belt, Northwest China. Int. Geol. Rev. 48:223-240.

Wu, H.; Feng, Y.; and Song, S. 1993. Metamorphism and deformation of blueschist belts and tectonic implications, North Qilian Mountains, China. J. Metamorph. Geol. 11:523-536.

Xia, L.; Xia, Z.; and Xu, X. 1995. Dynamics of tectonovolcano-magmatic evolution from North Qilian Mountains, China. Northwest Geosci. 16(1):1-28 (in Chinese with English abstract).

- 2003. Magmagenesis in the Ordovician backarc basins of the North Qilian Mountains, China. Geol. Soc. Am. Bull. 115:1510-1522.

Xia, X., and Song, S. 2010. Forming age and tectonopetrogenises of the Jiugequan ophiolite in the North Qilian Mountain, NW China. Chin. Sci. Bull. 55: 1899-1907.

Xiao, X.; Chen, G.; and Zhu, Z. 1978. A preliminary study on the tectonics of ancient ophiolites in the Qilian Mountain, Northwest China. Acta Geol. Sin. 52:287295 (in Chinese with English abstract).

Xu, W.; Zhang, H.; and Liu, X. 2007. U-Pb zircon dating constraints on formation time of Qilian high-grade metamorphic rock and its tectonic implications. Chin. Sci. Bull. 52:531-538.

Xu, Y.; Du, Y.; Cawood, P. A.; Guo, H.; Huang, H.; and An, Z. 2010. Detrital zircon record of continental collision: assembly of the Qilian Orogen, China. Sediment. Geol. 230:35-45.
Xu, Z.; Xu, H.; Zhang, J.; Li, H.; Zhu, Z.; Qu, J.; Chen, D.; Chen, J.; and Yang, K. 1994. The Zoulang Nanshan Caledonian subduction complex in the North Qilian Mountains and its dynamics. Acta Geol. Sin. 7:225241.

Xu, Z.; Yang, J.; Wu, C.; Li, H.; Zhang, J.; Qi, X.; Song, S.; and Qiu, H. 2006. Timing and mechanism of formation and exhumation of the northern Qaidam ultrahigh-pressure metamorphic belt. J. Asian Earth Sci. 28:160-173.

Xue, N.; Wang, J.; Tan, S.; Lin, H.; Li, W.; Ren, J.; and Liu, S. 2009. Geological significance of granite of Jinning age in Yeniugou-Tuole region on the northern margin of Central Qilian Block. J. Qinghai Univ. (Nat. Sci.) 27(4):23-28 (in Chinese with English abstract).

Yang, J.; Du, Y.; Cawood, P. A.; and Xu, Y. 2009. Silurian collisional suturing onto the southern margin of the North China Craton: detrital zircon geochronology constraints from the Qilian Orogen. Sediment. Geol. 220:95-104.

- 2012. Modal and geochemical compositions of the lower Silurian clastic rocks in North Qilian, NW China: implications for provenance, chemical weathering and tectonic setting. J. Sediment. Res., forthcoming.

Yang, J. S.; Xu, Z.; Li, H. B.; Wu, C. L.; Zhang, J. X.; and Shi, R. D. 2000. An early Paleozoic convergent border at the southern margin of the Qilian terrain, NW China: evidence from the eclogite, garnet peridotite and ophiolite J. Geol. Soc. China 43:142-164.

Yong, Y.; Xiao, W.; Yuan, C.; Li, J. L.; Yan, Z.; and Mao, Q. 2008a. LA-ICPMS zircon U-Pb ages of granitic plutons from the eastern sector of the Central Qilian and their geologic implications. Xinjiang Geol. 26:62-70 (in Chinese).

Yong, Y.; Xiao, W.; Yuan, C.; Yan, Z.; and Li, J. $2008 b$. Geochronology and geochemistry of Paleozoic granitic plutons from the eastern Central Qilian and their tectonic implications. Acta Petrol. Sin. 24:855-866 (in Chinese with English abstract).

Yu, J.; Li, X.; Ma, Z.; Sun, J.; and Wang, J. 2010. Chronological study of meta-acidic volcanics in Qingshuigou-Bailiugou ore field, Qilian County of Qinghai Province. Adv. Earth Sci. 25:55-60 (in Chinese with English abstract).

Yuan, G.; Wang, H.; Li, H.; Hao, G.; Xin, H.; Zhang, B.; Wang, Q.; and Tian, Q. 2002. Zircon U-Pb age of the gabbros in Luliangshan area on the northern margin of Qaidam Basin and its geological implication. Prog. Precambrian Res. 25:37-40 (in Chinese with English abstract).

Yuan, H.; Gao, S.; Liu, X.; Li, H.; Günther, D.; and Wu, F. 2004. Accurate U-Pb age and trace element determinations of zircon by laser ablation-inductively coupled plasma-mass spectrometry. Geostand. Geoanal. Res. 28:353-370.

Zhang, D.; Sun, G.; and Xu, H. 1995. Petrology and isotope chronology of the Jinfosi pluton, Qilian Mts., Gansu. Acta Geosci. Sin. 4:375-385 (in Chinese with English abstract). 
Zhang, H.; Jin, L.; Zhang, L.; Yuan, H.; Zhou, L.; and Zhang, B. 2006. Pb and $\mathrm{Nd}$ isotopic compositions of basement and granitoid in the Qilianshan: constraints on tectonic affinity. J. China Univ. Geosci. 31:57-65 (in Chinese with English abstract).

Zhang, J.; Mattinson, C. G.; Meng, F.; Wang, Y.; and Tung, K. 2008a. Polyphase tectonothermal history recorded in granulitized gneisses from the north Qaidam HP/ UHP metamorphic terrane, western China: evidence from zircon U-Pb geochronology. Geol. Soc. Am. Bull. 120:732-749.

Zhang, J.; Xu, Z.; Chen, W.; and Xu, H. 1997. A tentative discussion on the ages of the subduction-accretionary complex/volcanic arcs in the middle sector of North Qilian Mountain. Acta Petrol. Mineral. 16:112-119)(in Chinese with English abstract).

Zhang, J.; Xu, Z.; Xu, H.; and Li, H. 1998a. Framework of North Qilian Caledonian subduction-accretionary wedge and its deformation dynamics. Sci. Geol. Sin. 33:290-299 (in Chinese with English abstract).

Zhang, J.; Yang, J.; Mattinson, C. G.; Xu, Z.; Meng, F.; and Shi, R. 2005. Two contrasting eclogite cooling histories, North Qaidam HP/UHP terrane, western China: petrological and isotopic constraints. Lithos 84:51-76.

Zhang, J. X.; Meng, F. C.; and Wen, Y. S. 2007. A cold early Palaeozoic subduction zone in the North Qilian Mountains, NW China: petrological and U-Pb geochronological constraints. J. Metamorph. Geol. 25: 285-304.

Zhang, Q.; Chen, Y.; Zhou, D.; Qian, Q.; Jia, X.; and Han,
S. 1998b. Geochemical characteristics and genesis of Dachadaban ophiolite in North Qilian area. Sci. China (Ser. D) 41:277-281.

Zhang, Q.; Wang, C. Y.; Liu, D.; Jian, P.; Qian, Q.; Zhou, G.; and Robinson, P. T. 2008b. A brief review of ophiolites in China. J. Asian Earth Sci. 32:308-324.

Zhao, F.; Guo, J.; and Li, H. 2003. Geological characteristics and isotopic age of Tanjianshan Group along northern margin of Qaidam Basin. Geol. Bull. China 22:28-31

Zhao, G.; Wilde, S. A.; Cawood, P. A.; and Sun, M. 2002. SHRIMP U-Pb zircon ages of the Fuping Complex: implications for late Archean to Paleoproterozoic accretion and assembly of the North China Craton. Am. J. Sci. 302:191-226.

Zhou, Z.; Cao, X.; Hu, Y.; and Zhao, J. 1996. Early Paleozoic stratigraphy and sedimentary-tectonic evolution in eastern Qilian Mountains, China. Northwest Geosci. 17(1):1-58 (in Chinese with English abstract).

Zhu, B.; Kidd, W. S. F.; Rowley, D. B.; Currie, B. S.; and Shafique, N. 2005. Age of initiation of the India-Asia collision in the east-central Himalaya. J. Geol. 113: 265-285.

Zhu, X.; Chen, D.; Liu, L.; and Li, D. 2010. LA-ICPMS dating of the Wanggaxiu gabbro complex in the Dulan area, northern margin of Qaidam Basin, China, and its geological significance. Geol. Bull. China 29:227236 (in Chinese with English abstract).

Zuo, G., and Liu, J. 1987. The evolution of tectonic of Early Paleozoic in North Qilian Range, China. Sci. Geol. Sin. 1:14-24 (in Chinese with English abstract). 